
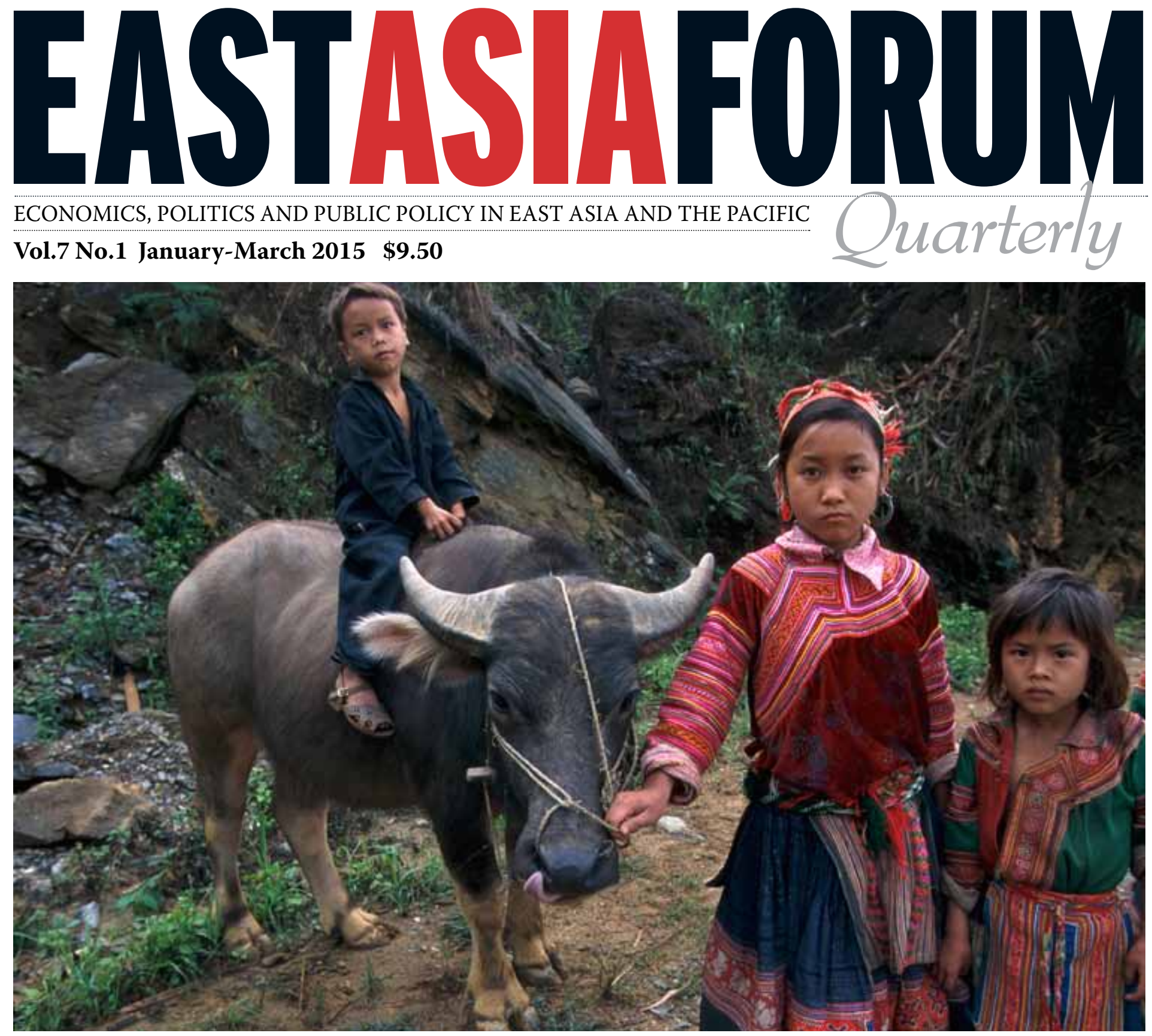

\title{
Asia's minorities
}

Nicholas Farrelly Compromise needed to solve Myanmar conundrum

Robert Barnett Minority and nation: making progress on Tibet

Tessa Morris-Suzuki Still a way to go for Japan's minorities

Cillian Nolan and Sidney Jones Jokowi's turn to solve the Papua question

Patricio N. Abinales Missing the peace in Muslim Mindanao ... and more

ASIAN REVIEW: Alok Sheel - can Modi hit the mark? 


\section{EASTASIAFORUM \\ Quarterly \\ ISSN 1837-5081 (print) \\ ISSN 1837-509X (online)}

\section{From the editors' desk}

Devoting an edition to minorities in Asia can appear a Sisyphean task. Discussion of the status of minority groups and government policies toward them is frequently politicised by history, memory, war, border politics, and broken promises. This snapshot of the status of ethnic and religious minority groups in the region highlights evolving policy frameworks and signs of progress in extending equal rights and protections to all citizens.

Progress in protecting minority rights varies greatly across the region. Some countries are going backwards. As Ihsan Ali-Fauzi and Ben Hillman observe, despite Indonesia's reputation as a tolerant and moderate Muslimmajority nation, the persecution of religious minorities has increased. In other countries, territorially concentrated minorities still struggle against the perceived injustices of majority rule. Patricio N. Abinales explains why, in the Philippines, a misreading of history continues to obstruct a peace deal with the Moro of Mindanao. The question of Tibet is similarly fraught with competing versions of history and national identities. Robert Barnett suggests how clearer problem analysis could point the way to a resolution.

Eun Jeong Soh outlines the difficulties for minorities in the Korean peninsula, where ethnic nationalism is hardening and ideas of multiculturalism have failed to take root. Nicholas Farrelly shows that democratisation in Myanmar has not dislodged notions of a single centralised union, where minority claims to self-determination and autonomy are vigorously rejected and forcibly kept in check.

Sebastien Carrier reminds us that not all minority concerns are political. Among the Hmong in China, for example, there are concerns for the protection of cultural rights, which are promised under the law but inconsistently delivered in practice. James Leibold adds to the discussion on China's ethnic minority policies, arguing that efforts to engineer 'ethnic harmony' have served to exacerbate ethnic tensions. Tessa Morris-Suzuki highlights Japan's progress in coming to terms with cultural diversity, but notes that policy frameworks have to evolve to ensure equal rights for minorities such as the Ainu, ethnic Koreans and more recent immigrants.

The Asian Review section provides reflections on key political developments in the region-including Alok Sheel on Modi's economic policy, Ilan Alon and Tom Lairson on Sino-Russian relations, Jacqui Baker on Jokowi's problems in Indonesia, and Ben Ascione on the impact of Japan's right wing on security policy.

\section{Ben Hillman and Ryan Manuel}



\section{ROBERT BARNETT}

Minority and nation: from paradox to resolution

\section{JAMES LEIBOLD}

Carrot and stick tactics fail to calm ethnic antagonism

\section{SEBASTIEN CARRIER}

Missing millions: the Hmong go uncounted

11 TESSA MORRIS-SUZUKI

Plus ça change: still a way to go for minorities

13 ALOK SHEEL

ASIAN REVIEW: Will Modi's arrows hit the mark?

16 JACQUI BAKER

ASIAN REVIEW: Jokowi's police go unpoliced

19 TOM LAIRSON AND ILAN ALON

ASIAN REVIEW: Disparities limit the scope for a strategic accord

21 BEN ASCIONE

ASIAN REVIEW: Abe's quest for collective self-defence

\section{CILLIAN NOLAN AND SIDNEY JONES}

Jokowi's turn to solve the Papua question

27 IHSAN ALI-FAUZI AND BEN

HILLMAN

New hope for Indonesia's religious minorities

\section{PATRICIO N. ABINALES}

Missing the peace in Muslim

Mindanao

\section{EUN JEONG SOH}

How ethnic nationalism undercuts multiculturalism

\section{NICHOLAS FARRELLY}

Compromise essential to resolve a conundrum

COVER: Hmong children. The Hmong are a recognised ethnic minority in many countries, including Thailand, Laos and Vietnam, but not China. PICTURE: Jeremy Horner / Panos Pictures. 


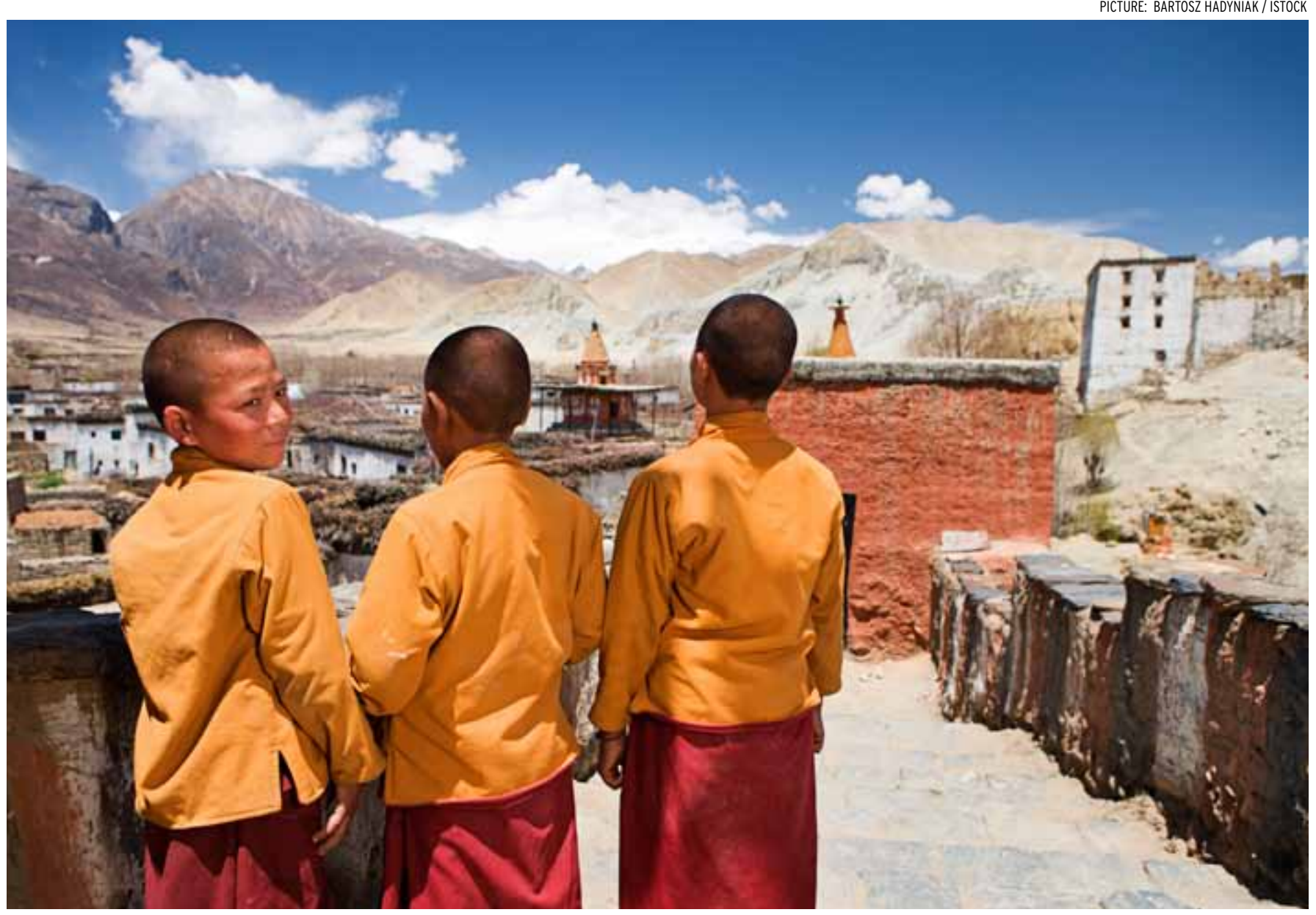

Looking homewards: novices at a Tibetan monastery in Mustang, Nepal. Many Tibetan exiles are banking on reforms in China to resolve the dispute.

\section{Minority and nation: from paradox to resolution}

\section{ROBERT BARNETT}

$\mathbf{T}$

HE Chinese authorities last met with representatives of the Tibetan exile leadership five years ago. Since then, no progress has been made towards a resolution of the ChinaTibetan dispute. Meanwhile, protests against Chinese rule have continued, with over a hundred self-immolations by Tibetans. The Chinese government has responded with tighter controls on movement, worship, speech and information in Tibetan areas, together with increased mechanisms for surveillance. But the reason for the failure to resolve the issue is not because of tensions on the ground. It's because of the inability of the two leaderships to agree on what the issue is.

There are two major views of the Tibetan situation. One view sees it as a minority question, where structural inequities in a society have been exacerbated by problems of religious difference and economic tensions. Chinese officials typically adopt this view, adding that these tensions have been exaggerated by outside agitators.

The other perspective, often found among Tibetans and Westerners, sees Tibet as a nation annexed by a large neighbour and denied its history. Expressing that view in China is likely to lead to a sudden end to any conversation, if not a visit by the police. The mutual distrust 
EASTASIAFORUM EDITORIAL STAFF

Issue Editors

Ben Hillman is Senior Lecturer in comparative politics at the Crawford School of Public Policy, ANU.

Ryan Manuel is Strategic Research Fellow at the Australian Centre on China in the World, ANU.

\section{Series Editors}

Peter Drysdale, Head, East Asia Forum and East Asian Bureau of Economic Research at the Crawford School of Public Policy, ANU.

Shiro Armstrong, Director, AustraliaJapan Research Centre and Executive Director, EAF and EABER, Crawford School, ANU.

\section{Editorial Staff}

Coordination: Owen Hutchison, Patrick Deegan.

Editing: Owen Hutchison, Patrick Deegan, Alison Darby, Linda Ma, Amanda Maclean and Alexia Fuller, ANU.

Editorial Advisers: Peter Fuller, Max Suich.

Production: Peter Fuller, Words \& Pics. Original design: Peter Schofield.

Email Peter.Drysdale@anu.edu.au, Shiro.Armstrong@anu.edu.au.

The views expressed are those of the individual authors and do not represent the views of the Crawford School, ANU, EABER, EAF, or the institutions to which the authors are attached.

\section{ANU PRESS}

Published by ANU Press The Australian National University Canberra ACT 0200, Australia

Email: anupress@anu.edu.au Web: http://press.anu.edu.au between holders of these two views incapacitates any talks between them.

Both sides have reasonable evidence to back up their perspectives. The ethnic tension view is supported by the fact that in the 13th, 18th and 19th centuries Tibetans were seen by the imperial court in Beijing as among its subjects. Today, they account for only 0.4 per cent of China's population, and over 80 per cent still live in the countryside (the figure in China as a whole is closer to 50 per cent).

Most informed holders of this view acknowledge that Tibetans face serious stresses on their culture and their language from internal migration and rapid development. But they see this as similar to the predicament faced by most minorities and a result of uneven development or competition in the marketplace. This is complicated in the Chinese case by limitations imposed on culture, religion and expression, but it still largely fits the standard model of ethnic discontent.

But in other ways the Tibet situation differs from minority issues of that kind. For most of the early 20th century, if not earlier, half of the Tibetan plateau constituted in practice a separate, treaty-signing nation. It had its own government and social system, and it had produced a vast and distinctive literature that is a noted part of world heritage, which all Tibetans are aware of. Few Chinese had ever been to the Tibetan region before Mao Zedong sent his army to take it over in 1950, and even today there are few Chinese who can speak or read Tibetan.

For Beijing, Tibet has other special features. It is a strategically significant area that represents a quarter of China's current territory. It sits between three nuclear-armed powers, two of which-India and Chinahave been involved in a long-running military face-off over the Tibetan border. In addition, the Tibetan plateau holds the sources for the rivers that supply most of China and much of South and Southeast Asia.

The Tibetan issue is also unusual in another respect: compared to long-running conflicts like Palestine, Chechnya or Darfur, the level of violence is exceptionally low. During the late 1950s and 1960s, when Tibetan armies or guerrillas fought with the Chinese forces, tens or hundreds of thousands died. But in the last 40 years unrest has taken the form of street protests, interspersed on just six or seven occasions by urban riots. Only about 20 or so Chinese have died from political violence by Tibetans over these four decades, mostly in one brutal incident in 2008. Approximately 300-400 Tibetans have been killed by security forces in the same period.

\section{Many urban Tibetans are}

now prosperous, and

\section{rural incomes are starting}

to rise

This low incidence of violence is due largely to the insistence of the Dalai Lama and is likely to be reversed immediately after his death. But it is one of several indicators that a resolution is still feasible. Each side has an undisputed leader who could sign a deal, the weaker side has long agreed on the need to compromise, and the two sides are-in principle-only arguing over one thing: what degree of autonomy Tibetans should enjoy. In addition, the current discrimination issues in Tibet are minor compared to those in conflict-zones worldwide. 


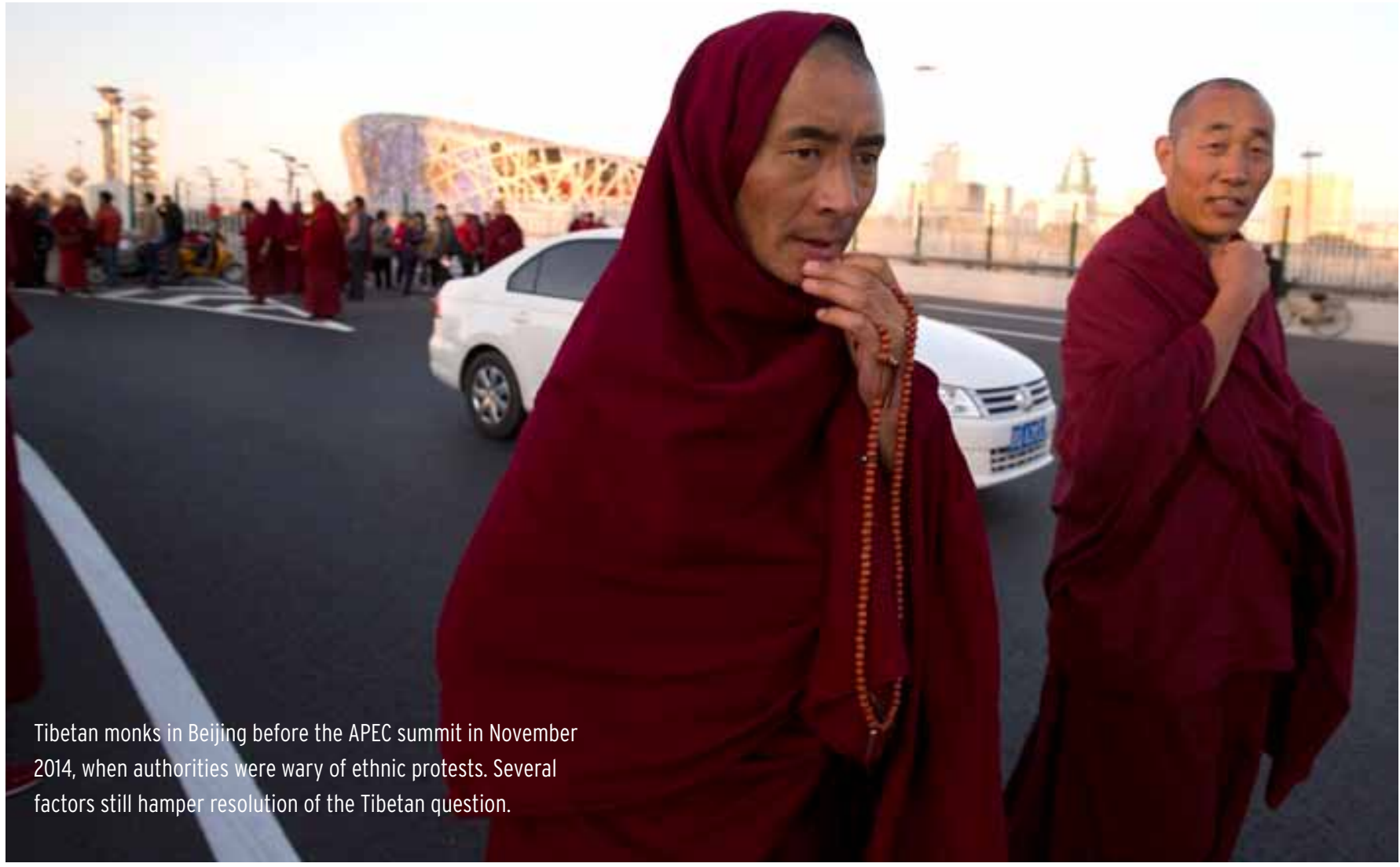

These are the marks of a dispute that is-for the moment-within reach of a political solution.

In 2018, when the current leadership of China will enter its second term, it will probably have removed many opposing interest groups and wiped out the deadweight legacy of Hu Jintao-era policy on Tibet. It will have new and younger leaders in place whom it has groomed for office, giving it a freer hand should it decide to introduce reforms. This is the scenario that the Tibetan exiles are gambling on as their best remaining hope for a solution.

But several factors hinder a solution. Most Western governments have bungled their handling of China's blustering style of diplomacy and have lost the little leverage they once had to encourage a negotiated settlement. Now only the US, India and Taiwan still have any chance of influence on this question. The Dalai Lama's success in getting world support since the 1980 s led to ten rounds of preliminary talks with China from 2002-10. But he has little time left (he turns 80 this year), urgently needs to find effective leaders to succeed him, and has wavered over recent issues like the self-immolations, to which he failed to call a halt.

The Chinese side faces even greater obstacles, such as entrenched conservativism within the bureaucracy. It has a long history of introducing policies that worsened rather than assuaged relations with its key minorities. But it needs to avoid anything that might look like a concession to outside pressure.

Yet China's underlying strategy in Tibet is finally beginning to show signs of success. For 30 years Beijing has been pouring money into infrastructure and economic growth there, hoping that this will lead Tibetans to become too invested in the economy to risk involvement in political unrest. Many urban Tibetans are now prosperous, and rural incomes are starting to rise. The political dividend of this economic growth is likely to be short-term, but it will delay and discourage any move towards a settlement by Beijing.

Despite these obstacles, the Chinese leadership might well decide that a negotiated solution to the Tibetan issue would be in its interests. But for that to be successful, Tibetan and Chinese leaders will need to recognise each other's views of the Tibetan situation, both as a site of ethnic tensions and as a place with a singular and distinctive past. EAFQ

Robert Barnett is Director of Modern Tibetan Studies at Columbia University, New York. 


\section{CHINA}

\section{Carrot and stick tactics fail to calm ethnic antagonism}

JAMES LEIBOLD

C OR centuries the Chinese state has governed its distant ethnic frontiers with both carrot and stick. In the past, emperors proffered 'imperial grace' (ēn) for those 'barbarians' willing to submit (at least nominally) to Chinese dominion, while reserving the right of 'imperial might' (wēi) for those who resisted. The èn/wēi stratagem continues in the People's Republic of China (PRC) today. But recent unrest in the Tibetan Autonomous Region, the Xinjiang Uyghur Autonomous Region and elsewhere reminds us of the inherent limits of these tactics of paternalistic co-option and repression.

Over the past decade China has witnessed an ugly spate of ethnic protest and violence, leading some to prognosticate a 'ticking time bomb' of inter-ethnic hostilities. In 2008, Tibetan areas erupted in protest and a year later nearly 200 people were brutally murdered in a bloody street riot in the Xinjiang regional capital of Ürümqi. Since coming to power in 2012, President Xi Jinping has faced a troubling wave of ethnic and religious embedded violence that has left nearly a thousand people dead. More worrying for Chinese leaders, the bloodshed is now spreading into major urban areas in China proper. The 2013 suicide car bombing in Tiananmen Square and 2014 Kunming train station attack, in particular, brought these once distant concerns to the very centre of power and public attention.
Yet these incidents are more cyclical and anomalous than systemic and incendiary. The increased density of transport and communication links engenders new spaces for ethnic misunderstanding and conflict in today's China, though it is impossible to say with any level of empirical certainty whether inter-ethnic relations are any worse (at a national level, at least) than they were a decade ago, let alone during the tumultuous Cultural Revolution. In managing these 'ethnic contradictions', the ruling Chinese Communist Party (CCP) relies on the same carrot and stick tactics as previous Chinese regimes: co-opting minority elites, encouraging and monitoring compliance at the grassroots level while eradicating pockets of resistance with brute force.

Nearly 7 per cent of all ethnic minorities in China are members of the $\mathrm{CCP}$ and many more are directly employed by the state. While most hold largely minor or ceremonial positions, some-such as the new director of the National Energy Agency, Nur Bekri, and the head of the Secretariat of the CCP Central Committee, Yang Jing-are in positions of real authority. Ordinary minorities enjoy a range of preferential state benefits, such as massive fiscal transfers and investment in minority regions; employment quotas in the public sector; bonus points on the university entrance exam; certain exemptions from family planning restrictions; and the right to preserve (within limits) their own cultures, languages and religions. Many minorities live in semi-autonomous administrative units and largely segregated ethnic communities.

Yet those that dare to openly resist CCP rule are efficiently and mercilessly silenced through the extensive domestic security apparatuses and judicial/extra-judicial legal system. China spends more on domestic security than it does on national defence. And the disparate punishments meted out to the Han intellectual Liu Xiaobo (11 years in prison for 'inciting subversion of state power') and the Uyghur economist Ilham Tohti (life in prison for 'separatism') highlight the different ethnic yardsticks for political loyalty in the PRC.

$\mathbf{T}$ HIS structure of ethnic clientelism buys a begrudging acquiescence and conformity among most ethnic minorities, but the lack of social cohesion (especially in Tibet and Xinjiang) impedes multi-ethnic interactions, inter-ethnic trust and the sense of shared national belonging necessary for a healthy civil pluralism. The result is a vexing nest of ethnic antagonisms that continues to serve as a significant yet manageable irritant for party leaders. China's ethnic troubles are nothing like those of Nigeria, Burma, Sri Lanka and other 'severely divided societies', where leading expert Donald Horowitz finds endemic ethnic conflict.

Despite their strategic distribution in resource-rich border regions, 


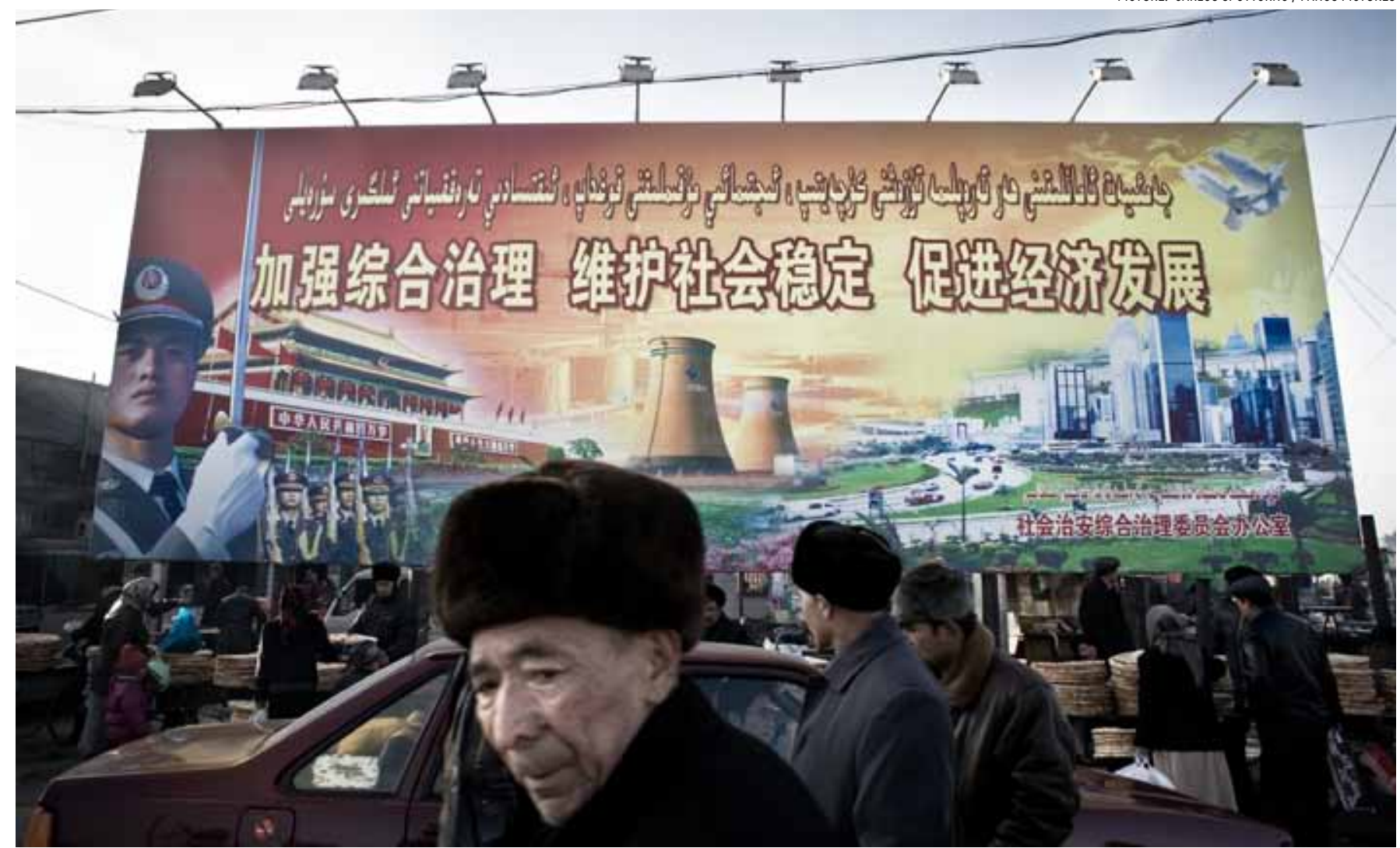

A billboard at a market in Kuqu, Xinjiang Province, encourages good relations between Uyghurs and Han, who make up an increasing part of the population.

China's ethnic minorities are far too small in number (about 114 million, or less than 9 per cent of the total population) and peripheral to the chief concerns of the party-state to pose an acute policy challenge. In fact, the divisions among those classified as part of the Han ethnic majority (along regional, cultural, linguistic, class and religious lines) pose a far more significant threat to $\mathrm{CCP}$ rule than the rift between the Han and nonHan minorities. The party-state might collapse one day but a USSR-style ethno-territorial implosion is highly unlikely.

Equally important, the coercive power and reach of the party-state ensures a level of stability that makes recent metaphors-Xinjiang as China's Chechnya and Tibet as China's Palestine-highly misleading. Like other multi-ethnic societies,
China faces a range of challenges in managing ethnic diversity but nothing on the order of an 'ethnic crisis'. In the past, a mere 20,000 officials governed the vast Qing empire; today, over 85 million CCP members and a further 10 plus million security personnel patrol nearly all aspects of social life. This far more intrusive and panoptic form of governance keeps a fairly secure lid on any immediate sources of instability while patching over longer-term social and political fragilities.

A T PRESENT, ethnic troubles are largely isolated to the remote and sparsely populated regions of Xinjiang and Tibet. Here inter-ethnic trust is in short supply, with a strong sense of ethnic, religious and physical difference. In the past, these regions experienced long periods outside the orb of Chinese influence. And today, many young Uyghurs and Tibetans struggle to adapt to a rapidly modernising society dominated by the Han Chinese language and culture.

In sum, the Chinese party-state expends considerable resources in an effort to engineer 'ethnic harmony'. Its authoritarian controls, ironically, attenuates ethnic contradictions in the short term, even if they erupt from time to time. Yet the lack of genuine openness, equality and grassroots community building forestalls the conditions required for a robust, inclusive and enduring ethnic pluralism. EAFP

James Leibold is a Senior Lecturer in Politics and Asian Studies at La Trobe University. He is the author of Ethnic Policy in China: Is Reform Inevitable? (Honolulu: East-West Center, 2013). 


\section{Missing millions: the Hmong go uncounted}

\section{SEBASTIEN CARRIER}

N RECENT years Uyghur and

Tibetan issues have captured most of the national and international attention granted to China's minorities. Yet Uyghurs and Tibetans account for less than 15 per cent of China's minority population of about 113 million. How have other large minority groups, such as the Hmong, fared politically, economically, and socially in the last decade? How well do the Chinese leadership's strategies and policies address ethnic minority challenges?

Overall, there is a clear gap between what is promised and what is provided to the less demanding minorities.

At a highly anticipated conference on ethnic affairs in the fall of 2014, President Xi Jinping emphasised that the Regional Ethnic Autonomy Law (1984) remains the cornerstone of China's ethnic policies. On paper, this law conforms closely to international human rights standards, guaranteeing numerous rights to minorities. They include self-government within designated areas, non-discriminatory rights, proportional representation, linguistic, cultural and religious rights, and the power to adapt central directives to local conditions.

China has 152 ethnic autonomous areas, including five autonomous regions, 30 autonomous prefectures and 117 autonomous counties, and more than 1090 ethnic townships. China's household registration system records around 70 per cent of the total ethnic minority population as resident in one of these autonomous areas.

Top Chinese leaders have also stressed that the government has undertaken a series of 'successful' programs and affirmative action initiatives for minorities in the past 30 years. For example, minorities have gained such privileges as partial exemptions from the one-child policy and preferential admission to institutions of higher education. They have also increased their representation in the National People's Congress, the government and the Chinese Communist Party (CCP).

The conference outlined two ways to further reduce ethnic discontent: economic development through increased investment in minority areas and a deeper campaign of 'patriotic'

In spite of their low

socioeconomic status,

the Hmong have not

yet politically expressed

a desire for self-

governance. Throughout

history they have never

been united politically education. This simple solution proposed by Xi's administration to ensure social harmony and prevent ethnic conflicts has been seen time and time again since the founding of the People's Republic of China.

But though China legally protects the distinctiveness and rights of ethnic minorities, many observers argue that legitimate representation, protection, and autonomy have yet to be achieved in practice. There are several key reasons why the Regional Ethnic Autonomy Law has been inadequately implemented.

First, while the law requires that the government head of an autonomous area be a member of the minority that exercises autonomy, this requirement has not been applied to the CCP leadership. The government head of the autonomous area reports to a party secretary, who is not necessarily a member of the ethnic minority but who exercises the main decisionmaking power in the region.

Second, the law specifies clearly that the interests of the state as a whole have precedence over the interests of any individual, minority or nationality.

The authority of the National People's Congress in autonomous areas is thus limited to the drafting of regulations, which must support the country's unity and respect the Chinese constitution, and also require approval from higher-level institutions.

Third, the government holds to its firm stance that China is composed of 56 official nationalities. 


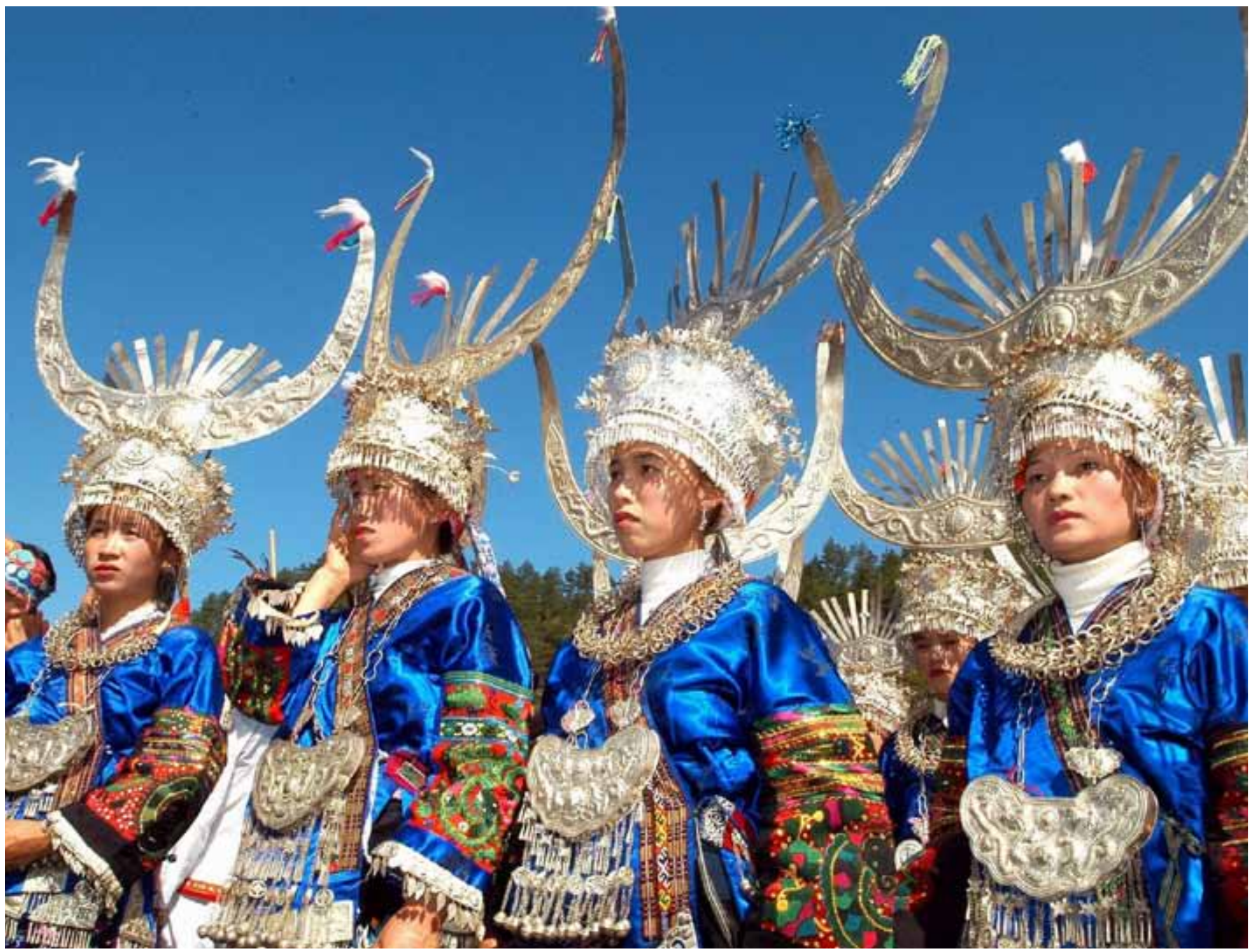

Women of the Miao people dressed in traditional costumes for a new year's celebration in Guizhou Province. The Hmong have not been recognised as a separate ethnic minority in China but have been combined with the Miao, a group whose identity more and more Hmong seem willing to adopt.

The implication is that no other nationalities could ever be recognised, a stance reiterated at the 2014 conference. With a population of approximately three million people scattered throughout the rural areas of Sichuan, Guizhou and Yunnan, the Hmong of China is one of the larger ethno-linguistic groups that have not been officially recognised as a nationality.

This omission may seem surprising since the Hmong are not only numerous but one of the few Chinese ethnic groups that has an extensive population living in countries outside of China. They are recognised as an ethnic minority by many countries, including Thailand, Laos, Vietnam and the United States.

In China the Hmong have been lumped into the Miao nationality, together with other ethnic groups linked more or less linguistically and historically to each other. Yet the Hmong have their own language, which is mostly unintelligible to other Miao. Despite this, there is little hope of official recognition among Chinese Hmong, whether by choice or because they sense the unwillingness of the government to reconsider its minority classification.

A growing number of Hmong seem to fully embrace the Miao identity in their relations with other Chinese and the state. Indeed, according to many Hmong elites, the fact that the Miao nationality is the fifth largest 'nationality' of China-with a population of over nine millionentitles them to a more favourable national status than would otherwise be the case.

In comparison with Uyghurs and Tibetans, discontent among the Hmong population has not led to a secession movement. Overall, 




Hmong children playing on a hillside. In China, the Hmong language has not been used in primary and middle schools and its use is declining among the young.

the Hmong's level of discontent is relatively low and comparable to that among rural Han Chinese. Their main criticisms are the lack of economic development within their areas, poor access to health services and lowquality education. The Hmong are still among the poorest and the least educated minorities in China.

In spite of their low socioeconomic status, the Hmong have not yet politically expressed a desire for self-governance. Throughout history they have never been united politically, which partially explains their lack of territorial ambitions. Furthermore, in most of the around 150 Hmong areas that are currently designated as Miao townships or autonomous areas, they coexist with other nationalities, complicating minority-related decisions.

The Hmong's main struggle involves the protection and the promotion of their own language and culture. The linguistic issues are twofold. Firstly, Hmong have rarely had access to government services in their own language, even though this is guaranteed by law. Therefore, with a Chinese illiteracy rate among the highest in the nation, Hmong of the older generations are de facto excluded from political and administrative spheres. Secondly, with a few exceptions, the Hmong language has not been used in primary and middle schools in Hmong areas. As a result, use of the language is declining among the young.
In the broader context of Southwest China, these linguistic issues demonstrate the differential application of China's ethnic policies. While Beijing guarantees language and cultural rights for minorities that jeopardise national security, it often disregards these rights for less organised or less threatening minorities. Southwest China's minorities also have yet to experience the right to self-governance or the opportunity to develop their territories. For now, better access to a quality education seems to be the only available means to improve their situation. EAFQ

Sebastien Carrier is Senior Programme Manager at Stepping Stones China. 


\section{Plus ça change: still a way to go for minorities}

\section{TESSA MORRIS-SUZUKI}

N AUGUST 2014 Yasuyuki

Kaneko, a city councillor for Sapporo, sparked intense controversy by tweeting 'there are no such people as the Ainu any more, are there? [But] they constantly demand rights they don't deserve. How can this be reasonable?'

The comments evoked an outpouring of criticism from Ainuthe indigenous people of northern Japan-and their supporters. But the blogosphere was also quickly filled with comments supporting Kaneko's views.
Kaneko was subsequently removed from the local Liberal Democratic Party caucus, of which he had been a member, but he remains on the city council and has refused to withdraw his comments.

This controversy recalls a notorious incident in 1986, when then prime minister Yasuhiro Nakasone stated in parliament that there were no minority racial groups in Japan and that Japan therefore had no racial discrimination. Those comments too provoked an angry response from many people, including prominent figures in Ainu and resident Korean communities. A comparison of the two statements, and of the reactions they produced, shows both how much and how little has changed in Japan over recent decades.

Although a city councillor can still make a statement like Kaneko's with scant damage to his career, it is hard to imagine a Japanese prime minister publicly denying the existence of Ainu or insisting on Japan's racial purity today. In 1986 the government had not yet officially recognised the Ainu as an ethnic minority. Large numbers of people in Japan still accepted that Japan was an ethnically homogeneous nation-despite the presence of not only the indigenous Ainu, but also of around one million Okinawans and

PICTURE: GIANFRANCO CHICCO / WWW.GCHICCO.COM




hundreds of thousands of descendants of colonial-era migrants from Korea, not to mention numerous other smaller migrant communities.

Since then, rising levels of immigration, cultural globalisation and the rise of minority rights movements at home and abroad have helped to change those perceptions and have resulted in some improvements for minority groups in Japan.

In 1986, the Ainu people were still subject to the antiquated and discriminatory Former Natives Protection Law, which aimed to eradicate their distinctive traditions, but (after lengthy protest campaigns) this was replaced in 1997 by an Ainu Cultural Promotion Law. In 2008, the Diet officially recognised the Ainu as an indigenous people.

In 2005 the number of foreign residents in Japan exceeded two million for the first time. Many political leaders, including Prime Minister Shinzo Abe, have acknowledged that Japan needs to further open its borders to inflows of foreign workers as the population ages and declines. Public recognition of Japan's ethnic diversity has been expanding, and many local governments now have active policies to promote 'multicultural coexistence' (tabunka kyōsei).

The 'Korean wave' of the early 2000 s created a new sense of cultural confidence amongst Koreans in Japan. Urban areas like the Tsuruhashi district of Osaka, with its large Korean community, began enthusiastically displaying and advertising their distinct cultural identity. In addition to the ethnic Korean population, whose origins go back to the colonial period, Japan now has substantial communities of more recent immigrants from Korea, China, South Asia and Southeast Asia, as well as ethnic Japanese Brazilians and Peruvians-descendants of prewar waves of Japanese emigration to Latin America.

But the wide online support for councillor Kaneko's statements on the Ainu is just one symptom of continuing deep-seated problems.

Legal protections for many ethnic minorities have certainly been strengthened since the early 1980s, but more comprehensive proposals for change-such as a radical revision of the immigration control system, recognition of dual nationality, or local voting rights for foreign permanent residents-have failed to get off the ground. The Ainu Cultural Promotion Law has also disappointed many within the Ainu community because it fails to recognise indigenous land or resource rights.

0 KINAWA, which was the independent Ryūkyū Kingdom until the 1870s, when it was absorbed into the Japanese state, is still Japan's poorest prefecture and is the site of large numbers of controversial US military bases. The expansion of these bases despite impassioned local opposition has left many Okinawans feeling that their interests are being sacrificed to the US-Japan alliance. An Okinawan independence movement, though still very small, has been gaining strength in recent years.

Meanwhile rising nationalist tensions between Japan and its neighbours have spilled over into troubling incidents of racial vilification by far-right groups. Drawing on the frustrations of Japanese whose living standards have suffered during decades of economic stagnation and channelling public anger towards minority scapegoats, these groups use street demonstrations and the internet to direct messages of hate and violence against Ainu, Koreans and Chinese in Japan, and others.

As it prepares for the 2020 Olympics the Japanese government has been highlighting Japan's multicultural credentials. The government has promised a new national Ainu cultural centre in time for the Olympics and is seeking to double the number of foreign visitors to the country. But its efforts to tackle issues of discrimination and racial vilification have been less impressive. Japan still has no national human rights commission and the government has rejected UN pressure to enact specific laws against racism and racial vilification.

In 2014 the ruling Liberal Democratic Party established a committee to examine the problem of hate speech, but the committee chair is a politician who has been an active campaigner against voting rights for foreign residents. So far the committee has debated limiting noisy political demonstrations outside government buildings and launched an investigation into 'anti-Japanese' rhetoric in Korea-two moves that suggest little commitment to the task of eradicating hate speech in Japan.

Prime Minister Abe has publicly stated that it is totally wrong to slander and defame people of other nations and hold the feeling that we are somehow superior. That would only lead to dishonouring ourselves'. But to give life to such statements, Japan needs much stronger and more effective strategies to celebrate ethnic and cultural diversity, and protect social justice. EAFQ

Professor Tessa Morris-Suzuki is an ARC Laureate Fellow at the School of Culture, History and Language at the College of Asia and the Pacific, The Australian National University. 


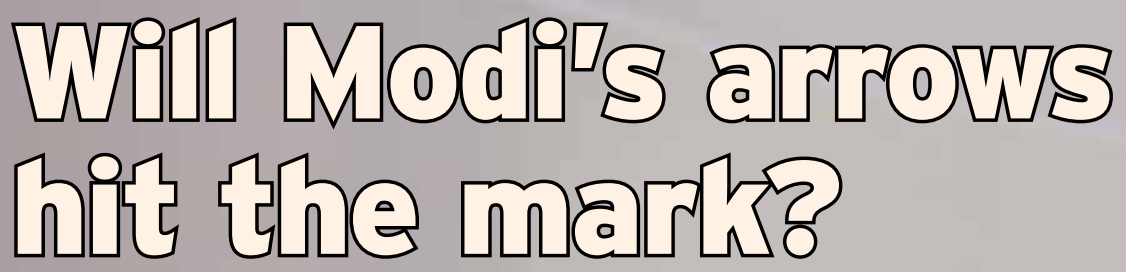

Prime Minister Narendra Modi: his government has renewed optimism for India's recovery.



ALOK SHEEL

A VISIONARY new leader, Narendra Modi, has recently come to power in India. He seeks to realise India's huge growth potential and make it a major global player. This has generated enormous optimism nationally, and internationally, about an Indian resurgence. What challenges must India overcome to achieve this?

At the turn of the 20th century, India was struggling to free itself from colonial rule. A century later, on 4 September 1999, The Economist despaired at India's untapped potential, labelling it 'the world's biggest under-achiever'.

Shortly after, India became the second fastest growing major economy in the world. Foreign investments surged. The popular account of India's story was that India was a big and fast-growing economy with a young demographic profile. It had an abundance of cheap labour with huge scope for large productivity shifts. Its entrepreneurs were in the forefront of the IT revolution and in leadership positions in transnational corporations. The only hurdle in the way of India's economic take-off was the lack of structural reform.

But a rising tide lifts all boats. The opening decade of the 21st century was also a period of unprecedented global growth. Be it as it may, India, along with China, also weathered the early blows of the global financial crisis of 2008 reasonably well. As China struggled to rebalance its economy, India's resilience was attributed to its greater reliance on robust domestic demand as its engine of growth. India seemed to have, at last, taken off.

But, beginning in 2011, the Indian economy went into a downward spiral of almost 12 successive quarters of falling growth, including several quarters of below 5 per cent growth. Several near-term indicators-such as industrial production, agriculture, exports and the real estate sectorremain depressed. Uncertainty surrounding US monetary policy threatens the recovery. Inflation and the current account deficit have declined impressively, but this is consistent with both low demand and sound macroeconomic management.

The Modi government has renewed optimism in India's recovery. There is a broad consensus that structural reform should centre on three critical economic policy arrows, and the new government seems intent on pursuing these. The first arrow is agriculture, where major market failures have made consumer price inflation 
endemic. The second arrow comprises the clutch of reforms to facilitate labour-intensive manufacturing to make the government's 'Make in India' campaign reality. The third arrow is fiscal restructuring to free up taxpayer resources for major investment in physical and social infrastructure.

These policy arrows need to fire from a robust bow of good governance that breaks loose from the extant bureaucratic and political system that has hobbled the delivery of policy in the past. State dominance over economic activity has led to inertia and corruption at each step for decades.

B UT is it possible that India could once again miss the bus? Is India still the world's biggest underachiever?

The vast potential of India is undeniable. It is often traced back to the time before the Industrial Revolution when India and China were the biggest and most prosperous economies in the world. There were good reasons for this dominance. The Indo-Gangetic floodplain was one of the most fertile and productive in the world. It supported population densities rivalling industrial counties in nineteenth-century England. Seedyield ratios for major cereals were about 2-3 times those in late medieval Europe. There were two crops year after year without fallowing, compared with every three years under the threefield system in Europe.

These high levels of productivity spawned a sophisticated division of labour. Unsurprisingly, India stood at the centre of the two dominant ancient trade routes-the Silk Road and the Indian Ocean. On the eve of the Industrial Revolution India was the biggest exporter of cotton textiles.

Following the unprecedented and rapid productivity shifts of the Industrial Revolution, India fell far behind Western economies. This led, almost inevitably, to imperial domination.

India nevertheless bounced back to be at the forefront of anti-colonial movements from the late 19th century. When it finally attained independence from foreign rule in 1947, it was one of the most advanced 'developing countries'. The foundations of a modern infrastructure of metalled all-weather roads, canals and railways had been laid and there was a strong indigenous modernising impulse.

But, a growing East Asia left India far behind. In 1980, income per capita in China and India was roughly the same. Today China's is $4-5$ times higher. This is perhaps what inspired the damning verdict of The Economist and now gives one a sense of déjà vu.

So what can India do to achieve its potential?

Beyond the three major structural reforms there are, arguably, three fundamental factors holding India back. These operate at three interrelated but heuristically distinct planes: economic, cultural, and social.

On the economic plane, the chief constraint is the failure to strike the right balance between the market and the state. There is a close correlation between economic freedom and high median per capita income. The reason for this is startlingly simple: free markets and trade maximise efficiency and productivity growth through the time-tested principle of comparative advantage. The world's fastest growing economies started growing rapidly only after opening up.

Fear of the market has long pervaded economic policy and civil society in India. This fear has tilted the balance between the market and the state sharply towards the latter, undermining economic efficiency and productivity growth. Crony capitalism, or rent seeking, was the direct outcome of this imbalance. Despite significant economic liberalisation since the early 1990s, India remains among the most protectionist, economically unfree and challenging business environments. It is still not clear whether the new administration would open up markets or try and emulate the East Asian statist model of command and control capitalism that may yield spectacular returns over the short run.

$\mathbf{T}$ HE state no doubt has a critical role to play in regulating markets and providing public goods. Adam Smith noted that participants tend to abuse the market, necessitating state intervention. But there can also be state failures and markets often fail because of excessive state intervention. Agricultural commerce in India that prevents farmers from selling directly in the open market is a case in point. Like all monopolies, state monopolies risk becoming inefficient in the absence of competition, and are also eminently corruptible

But even as the state has overextended itself in market regulation, control and substitution, it has not invested sufficiently in critical physical and social infrastructure, where private enterprise has much less of a role to play. This has constrained productivity and income growth.

While the fear of markets has tended to limit efficiency and productivity gains, India's predominantly inward orientation has constrained competitiveness in a rapidly integrating global economy. India is now an outlier among emerging market economies in running structural current account deficits. 
Despite the far-reaching trade reform of the early 1990s, India remains one of the most protectionist of the world's major economies. This inward orientation is difficult to fathom because of India's strategic location between East and West and the global spread of India's entrepreneurial diaspora. Also, whenever India has engaged economically with the world, whether through merchandise trade in premodern times or through services trade today, it has consistently been a world leader.

This insularity was best articulated over a thousand years ago by the Arab scholar al-Biruni who suggested that Indians did not feel the need to learn from the rest of the world, or indeed to engage with it intellectually.

This sense of Indian exceptionalism and inward orientation persists to this day, including amongst fringe elements in Modi's own party. While East Asia scours the world to learn and implement global best practices in a bid to catch up rapidly, India seems to think that it is different, has little to learn from the experience of others and must chart its own unique policies. There is, of course, no need to uncritically follow everything Western, but if India is to tap its potential, and not fall behind yet again, it needs to engage more with the outside worldboth West and East.

India must also address social inequalities that limit equal access to opportunities.

\section{A GOOD way to underscore the critical importance of social} constraints is to ask why the third largest economy in the world-and the world's biggest democracy, comprising about one-sixth of humanitystruggles to win a single gold medal at the Olympic Games. Does this reflect a lack of talent or a lack of opportunity?

The caste system has long been a defining feature of India. It segmented society into communities with limited social contact and gave asymmetric, hierarchical access to opportunities.

Extreme forms of socioeconomic disenfranchisement, such as untouchability, have loosened considerably, especially in fastexpanding urban spaces. But the lingering effects of the caste system still segment access to opportunities and undermine the dignity of labour in civil society at every level. It is difficult to explain to Westerners why the lady of the house and the maid cannot sit together at the same table over tea and engage in small talk, woman to woman.

A startling outcome of these lingering effects is India's poor human development indicators. On average, even sub-Saharan Africa does better nowadays. This cannot be attributed to scarcity of resources because the state has pampered a large middle class, at the expense of investment in social infrastructure for those on the margins of society.

Yet it is not the moral argument against inequality - strong as it isthat needs to be underscored, but the economic one. A large chunk of the population is denied opportunities for educational and skills advancement. The full potential of the nation's enormous talent pool cannot be tapped.

India's poor performance in the Olympic Games is only one symptom of its overall underachievement according to global benchmarks. This extends to basic student skills in rural schools, the output from our higher and technical education institutions, research, and various areas of economic activity. India's best talent may be invisible because it is not given an opportunity to develop and achieve.

This is yet another area where the state-market balance has floundered. The state has tried to equalise outcomes through reservations, regulation and poorly targeted redistribution that puts increasing restrictions on the market. Instead the state should put in place the infrastructure to equip every individual to effectively compete and expand incomes under a market framework. The tendency to shift the burden of social protection from state to non-state market participants, such as private corporations (through stringent labour laws) and schools (through a quota system) has resulted in a vicious cycle of decapitalising affected sectors or pushes them towards informality. This depresses investment, productivity and growth, and further constrains tax revenues that could be used to redistribute resources.

\footnotetext{
$\mathbf{F}$
} REE markets do not, of course, lead to equality of outcomes.

But they also abhor poverty that depresses demand and stifles growth. Public goods and social protection can be provided most effectively when markets grow. But cutting the cake into smaller pieces only equalises misery. In the absence of growth India risks falling into the politically volatile middle-income trap.

The global economy is still recovering from the biggest financial and economic crisis since the Great Depression of the 1930s. The old growth model, based on leveraged consumption in advanced economies, has broken down. A major global rebalancing of demand and structural reforms is required to get growth back on track. A stagnant global economy is an economy in search of new engines of growth. 
India could be this new engine of growth. Though the medium-term prospects of a robust global recovery are distinctly downbeat, there is reason for cautious optimism with regard to India in the short term. The two major drivers that recently pushed Indian trend growth from 5.5-6.5 per cent into the 8-9 per cent trajectory are intact. The dependency ratio continues to decline, while the roughly 10 per cent increase in domestic savings, as a share of GDP, is largely intact except for some short-term damage to financial savings.

Unlike other emerging markets that are dependent on external levers to return to high growth, India's economy is balanced. The necessary reforms are mostly domestic, making now the opportune time for an Indian resurgence.

To realise its vast potential, India needs major policy and structural reform over the short- to mediumterm. In particular, it needs to fire three arrows-agriculture, labourintensive manufacturing and fiscal restructuring-from the bow of good governance.

Pulling these three strings is the immediate challenge for the Modi government in New Delhi over the short to medium term.
But if India is to sustain high growth over an extended period, beat the middle-income trap and become a major global player, it also needs to change its mindset. Civil society needs to overcome its fear of markets, engage more fully with the outside world and empower its citizens with equal opportunities. The real wealth of nations lies in their people. EAFQ

\section{Alok Sheel is the Additional Chief} Secretary in the provincial government of Kerala. He was previously the Secretary of the Prime Minister's Economic Advisory Council, India.

\section{Jokowi's police go unpoliced}

\section{JACQUI BAKER}

$\mathbf{R}$ ARELY do the police figure in studies of politics. Of all the institutions of the state, police are the great wallflowers of the political party. They are not known for their great generals or their formidable political veto power. And yet, 100 days into the much-anticipated presidency of Indonesia's Joko Widodo (Jokowi), it has been his failure to manage the complex and nuanced politics of the police that has not only brought about the downfall of Indonesia's highest crimefighter but exposed Jokowi's personal and political weaknesses.

When rumours spread around Jakarta that Jokowi was intent on replacing the National Police Chief, General Sutarman, there was understandably some surprise. After all, Sutarman was a reasonably competent cop, nominated by the last administration and still with a solid six months to his term. But a new administration often requires new leadership and so speculation turned to a handful of names of similarly passable officers who might replace him. In principle, the president, in consultation with the National Police Commission, is free to nominate multiple candidates whose names are then put forward to the House of Representatives to assess. On 9 January 2015, Jokowi followed his predecessor's practice by nominating a single candidate: Budi Gunawan.

That Gunawan would be one of the names in circulation was also no great surprise given his closeness with Megawati Sukarnoputri, Jokowi's political patron and the head of his party, the PDI-P. Gunawan served as adjutant during Megawati's presidency and vice presidency. Within police circles, Gunawan is known as a major broker, able to insert himself in the most powerful and lucrative networks. As assistant to the Deputy for Human Resources under former police chief
General Sutanto, Gunawan's personal wealth had inexplicably ballooned.

Later stints as chief of police in Jambi province and then at police headquarters as head of internal affairs further amplified his authority. Although Gunawan had been cast out under Sutarman to the political wilderness of police education, this did not limit his financial prowess. His 2013 personal wealth statement was 21.5 billion rupiah (about US $\$ 1.7$ million). Such was the extent of Gunawan's wealth, and the speed with which he accumulated it, that Gunawan was repeatedly rumoured to have one of the 'fat police bank accounts' monitored by the Centre for Indonesian Financial Reports and Analysis.

\section{NDONESIAN civil society and} intelligentsia reacted to the nomination with shock and outcry. But in the days that followed, Indonesia's Anti-Corruption Commission (KPK) 


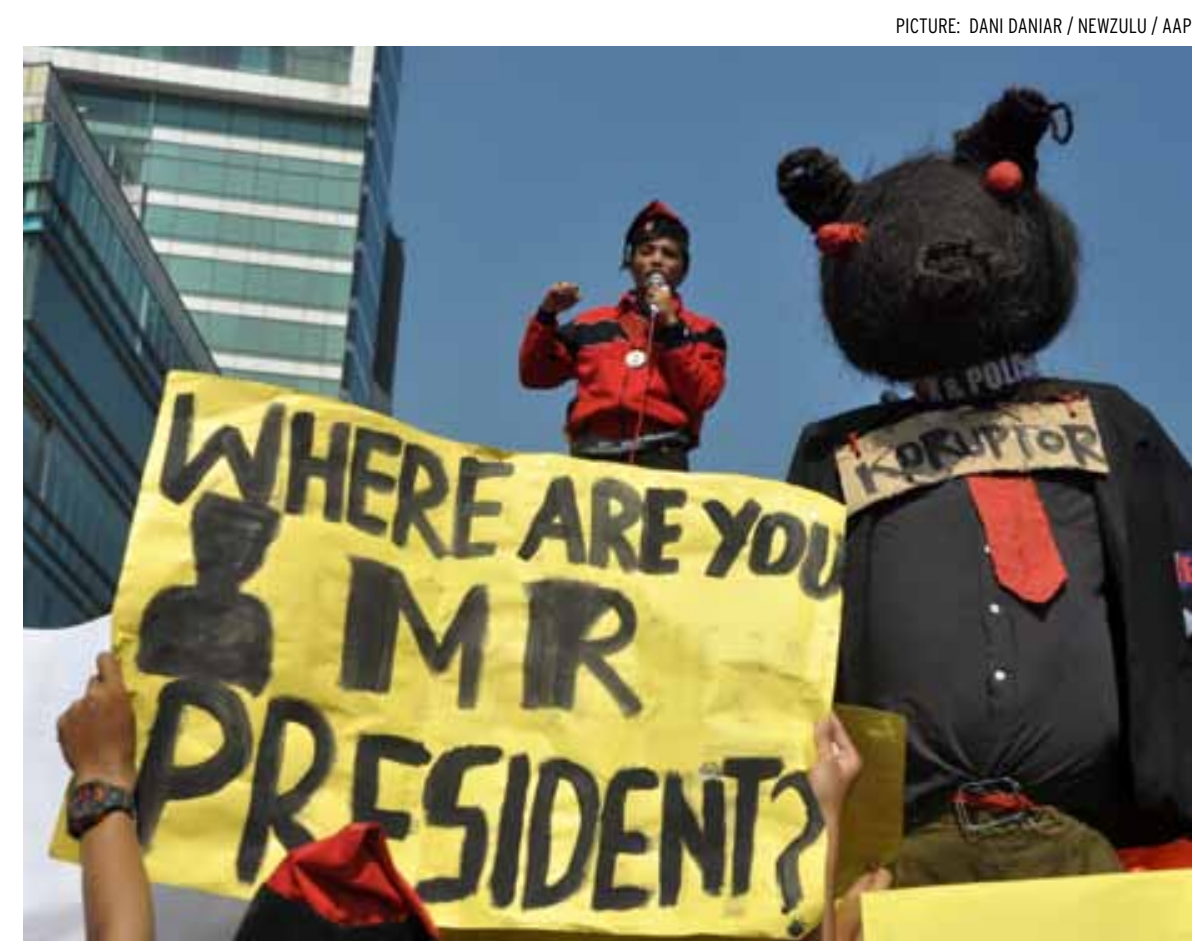

A speaker rallies the crowd at a demonstration in support of the KPK in February 2015.

took matters one step further. The KPK had reportedly red-flagged Gunawan in their review of potential ministers for Jokowi's new cabinet. Just four days after Jokowi's nomination of Gunawan, KPK head Abraham Samad and deputy Bambang Widjojanto declared the would-be police chief a corruption suspect.

The KPK has long believed itself to be the moral guardian of Indonesian democracy. A number of public statements from Samad in the first months of Jokowi's term implied that not only was the KPK's authority above and beyond that of the president but that his very electoral success had been aided, at least in part, by KPK's tacit endorsement of him as a clean candidate. Throughout Jokowi's campaign and early presidency, the commission had made its political preference for his presidency clear, even taking out rival Prabowo's running mate Suryadarma Ali midcampaign on corruption charges. Yet even in this highly politicised environment, the KPK's retrospective announcement of corruption charges on a presidentially endorsed appointee was at best courageous and, at worse, downright provocative.

In the fracas that followed, the Gunawan nomination was stalled, and at considerable cost for all involved. General Sutarman was swiftly retired and his Chief of Criminal Investigations ousted, replaced by Budi Waseso, a key Gunawan ally. Badrodin Haiti, an unremarkable deputy police chief who himself has been accused of having a 'fat bank account', ascended to take on the top job.

B UT even Haiti wasn't informed when, ten days after the KPK's naming of Gunawan as a corruption suspect, criminal investigators under Waseso arrested the KPK's Bambang Widjojanto. In the subsequent weeks Waseso has been relentless, resurrecting numerous cold cases against Samad and two other KPK deputies, effectively wiping out the
KPK's leadership and threatening its remaining investigators with criminal charges.

Most recently charges against two KPK deputies have been dropped, but Samad and Wijojanto remain under investigation. Meanwhile Waseso's office has wrested control of the Gunawan corruption case after a Jakarta court ruling, a first in the history of the KPK.

Given their fractious history, it is hardly surprising that the police would respond so aggressively. In 2009, the KPK clashed with the police over the arrest of a police general, which saw two KPK commissioners arrested on fabricated charges, while in 2012 a spat over the procurement of traffic simulators saw the police attempt to raid KPK offices ostensibly to arrest an investigator on trumped-up charges.

But in the years since their last public battle, the two institutions have increasingly come to an uneasy acknowledgement of their interdependence. In large part this is because the KPK has finally accepted that if Indonesia is ever to be free of corruption, then the KPK will have to give up its monopoly stake in the war against it.

There is a strong legal basis for further narrowing and refining of KPK's role. Although the KPK has made its name by investigating and prosecuting corruption, the legislation states clearly that the KPK's principal job is to coordinate and supervise the corruption investigations of other law enforcement institutions, particularly the police. The KPK's belated understanding of the shared nature of the fight against corruption has been, for the police, a major source of frustration and has fuelled accusations that the institution is an arrogant super-body.

The current dispute is not all about 
functional overlap. The KPK enjoys public support that is unprecedented for an Indonesian state institution. Meanwhile, the only poll that the police seem to top is Transparency International Indonesia's 'most corrupt' perception index. And yet KPK investigators are nothing more than police officers on secondment. It's in the well-resourced, respected halls of the KPK that police officers reach new heights of investigative skill and professionalism.

Former National Police Chief General Sutarman and Chief of Criminal Investigations Suhardi Alius understood that if the police were going to improve their public image, then the force would have to lift its game in corruption investigations. The way to do that was to attract this cohort of well-trained investigative officers back to the ranks of the police. By revamping and refunding their Special Unit for Corruption Crimes and stocking it to the brim with newly returned KPK investigators, the previous leadership indicated that they were both serious about an anticorruption drive and that people-topeople relations would spearhead the relationship.

The Gunawan affair has revealed just how quickly institutional lines can be drawn. Waseso's dark comments about cleansing the police force of 'traitors' suggest that the time of rapprochement, and by extension, any hope of a coherent and consolidated anti-corruption drive, is for now well and truly over.

But the current push against the KPK is not just fuelled by a history of institutional rivalry. The depth and success of this attack on the KPK suggests that the police are supported by the highest echelons of the political establishment.

The KPK has unsurprisingly few

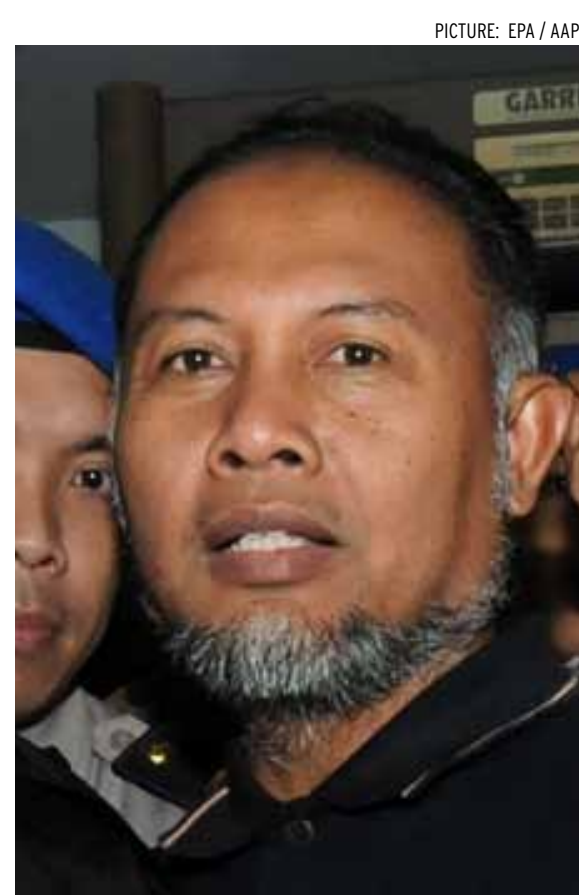

Under attack: Bambang Widjojanto, deputy head of Indonesia's anti-corruption authority.

friends in parliament and the past few years have seen a number of failed legislative attempts to weaken the agency's authority. But this time, Indonesia's fractured parliament has coalesced behind the driving force of Megawati Sukarnoputri, head of the PDI-P and Jokowi's political patron. Last year, the KPK reopened an investigation into the terms under which then president Megawati, by presidential instruction, released a number of companies from the obligation to repay their money from a Bank of Indonesia bailout. In the months before his arrest, KPK head Samad was forthright in his promise to bring Megawati before the commission.

Megawati has scarcely appeared in public since the Gunawan nomination, but her ruthlessness and obstinacy in the face of public fury speaks volumes about the dynamics of her relationship with Jokowi. While Megawati sat regally silent, party hacks like Effendi Simbolan mused on the possibility of a presidential impeachment with a spite to rival anything that has so far come from the opposition.

PDI-P has revealed itself to be an insular, often myopic party, even when this threatens the credibility of its very own government and with little affection for the man who put them there.

Megawati has been unflinching in her support for Gunawan, even in the face of public outrage. Jokowi's current proposal to nominate Badrodin Haiti as police chief with Budi Gunawan as his deputy illustrates just how little space the president has with his political partners for compromise.

While PDI-P has exposed its true colours, the real damage has been done to Jokowi himself. Jokowi's performance has been one of blundering, foot-dragging and a desperate lack of political smarts. From the beginning, Jokowi appeared unprepared for the indignation that the Budi Gunawan nomination would ignite, highlighting his patchy grasp of portfolios that don't immediately interest him.

These weaknesses we glimpsed during his poorly organised, often flatfooted, presidential campaign. But the politics of the police have stripped Jokowi of his reformist image, revealing a man who not only appears lacking in political acumen and leadership skills but is also hemmed in by the very forces that are supposed to be on his side. If in just six months of the Jokowi government the KPK, Indonesia's most celebrated state institution, can be brought to its knees, then it's going to be a long fourand-half years ahead. EAFQ

Jacqui Baker is a Lecturer in Southeast Asian Studies at Murdoch University and a Fellow at the Asia Research Centre. 


\section{Disparities limit the scope for a strategic accord}

PICTURE: SERGEI ILNITSKY / EPA / AAP

TOM LAIRSON AND ILAN ALON

D OES the geopolitical relationship between China and Russia portend a major shift in global relations or is it merely an arrangement with a limited impact? Many observers focus on the similarities in these nations as the basis for expectations of a deepening relationship. The long common border, communism and authoritarianism, corruption, wariness of Western powers, BRICS status and the apparent alignment of interests all seem to point in the same direction.

But, despite these commonalities, Russia and China are unlikely to develop more than a tactical and limited relationship.

Vladimir Putin has spent much of the past 15 years reshaping Russia's relationship to a global system dominated by liberal Western capitalist states. The domestic system of kleptocracy in Russia permits only a shallow integration with this system, limited to trade and oil-related investment. By contrast, China is now deeply integrated into the global capitalist system, based on a globally competitive economy and effective political system.

The Russian system of government under Putin is predatory and organised to generate large gains to a tiny elite. Bribery is the main channel. Approximately 35 per cent of Russia's national wealth is controlled by 110 extremely rich Russian oligarchs, with very close connections to the

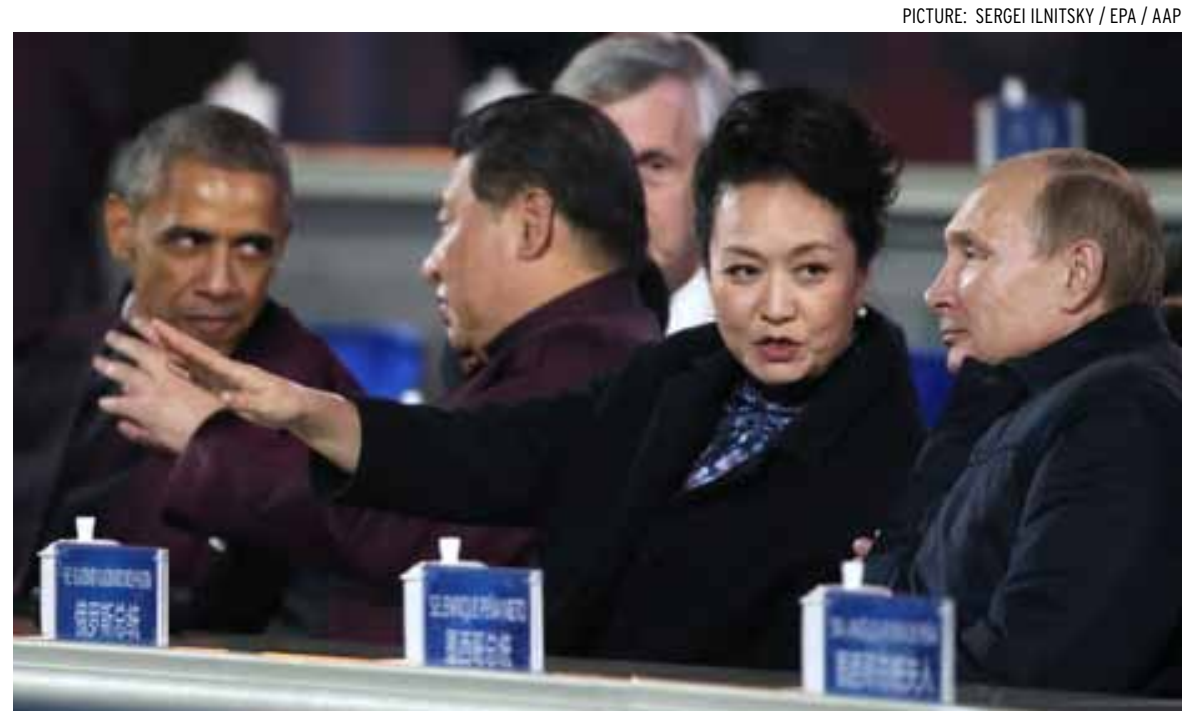

Power bloc at the Beijing APEC summit in November 2014: Presidents Barack Obama and Xi Jinping in discussion, left while Peng Liyuan, wife of President Xi, engages Russia's President Vladimir Putin.

state. Putin himself has become extraordinarily wealthy. The contemporary Russian political order has been reconstructed around many of the same features as was the Russian state under Stalin and the tsars. The system has been held together through an ideology of rabid nationalism, intense xenophobia, the appearance of democracy and economic growth fuelled by high oil prices.

Many would point to similar features in China, emphasising corruption, princelings and the absence of even the appearance of democracy. But the deeper features of kleptocracy in Russia are quite different from the situation in China and call for important distinctions, especially in political economy.

China is certainly an authoritarian society, but its political system is quite different from Russia's. The political and economic elite in China is large. It includes a variety of economic elites that are widely distributed geographically. Chinese Communist Party (CCP) members are recruited using meritocratic standards, and the party operates to generate effective governance down to provincial, city and village levels.

Perhaps most important, since 1978 China's Communist Party has been in charge of the largest and longest period of economic growth ever recorded. Mobilising capital for nation-wide investment, restructuring the economy, opening to global investment and prices, and building up local firms-state-owned and private-able to operate successfully in a highly competitive economy is a remarkable feat. The Russian kleptocracy's only economic success under Putin has been to sell oil at 
global prices, which exposes Russia to considerable pain and few options when oil prices fall by 50 per cent.

An analysis of the two economies provides the basis for understanding their divergence. Both countries rely on international trade and investment. China and Russia are significant players in global trade, but China is much larger. China's economy is 5.2 times larger, inflows of foreign direct investment are 2.5 times larger, its inward foreign direct investment stock is 4.2 times larger, and exports and imports are 4.1 and 4.6 times larger, respectively. Both countries rely on trade for the acquisition of technology, raw materials, machinery, pharmaceuticals and other socioeconomic building blocks.

But while China consumes 6.8 per cent of Russian exports (second only to the Netherlands), Russia is not a major consumer of Chinese exports. The US consumes 16.7 per cent of China's exports and is the largest consumer market for its products. China's economic reliance on the US is much higher than that on Russia.

B UT there are even deeper distinctions in the Russia and Chinese economies. Russian stateowned enterprises (SOEs), lacking the exposure to global competition experienced by Chinese SOEs, are extremely inefficient and require protection from the rest of the world. The Russian kleptocracy prevents the development of competitive enterprises, especially in those SOEs closely tied to the system.

Compounding the lack of globally competitive firms is the extremely narrow basis of the Russian economy, which is highly dependent on oil, natural gas, and similar products. The recent collapse of oil prices exposes this dependence and Russia to the need for extensive austerity. But such a policy would conflict with the core system of rule by the kleptocracy and therefore challenges the state itself. Kleptocracies work when increasing spoils are distributed to the oligarchs. But with austerity reducing the spoils, conflict among oligarchs is likely to increase. Further, Russian integration with the global economy is substantial but narrow. This leaves little capacity to adapt to the constraints of the global economy, including sanctions from the West and low oil prices. The Soviet Union tried to build an economy entirely apart from the Western system. That experiment clearly failed.

By contrast, the Chinese leadership has consistently pursued an economic strategy based on an ever-deeper integration into the global economy. Global prices and firms intersect with increasingly expansive domestic markets and capable Chinese firms to create a competitive economy.

A competitive economy aligning with an uncompetitive one does not offer a promising basis for a strategic relationship. The superficial similarities between Russia and China are not a promising basis for a strong geopolitical relationship. China may have a stronger cultural affinity with the US than with Russia. But, perhaps there are other reasons for the relationship in a set of overlapping geostrategic interests.

Global politics is usually seen in terms of strategic interests. It is often defined by common enemies, which bind nations into a close and strong relationship. Can this serve to bring Russia and China together? There are good reasons to doubt such an outcome. Sino-Russian and Sino-Soviet relations have both been partially defined by conflicting interests and intense hostility, and this legacy weighs on the present.

Much of this is linked to longstanding boundary conflicts, which culminated in military conflict in 1969. In the 1950s, during the decade-long period of the Sino-Soviet Alliance, Chinese leaders concluded that the Soviets were unreliable allies in protecting China from a US nuclear attack. By the late 1960s, Mao Zedong had resolved that they were the greater threat to China. The semi-alliance between the US and China from 1972 to 1991 was premised on mutual fears of the Soviet Union.

Now the question is whether a new shift is occurring, one that would see China and Russia aligning against a perceived major security threat from the US. Can the two provide each other with important gains by jointly resisting the US?

$\mathbf{T}$ HE potential 'partnership' between China and Russia becomes much clearer if we understand the shifting structure in global relations. First, alliances of the 19th and 20th centuries-in which nations were bound to each other for some potential war-are of little relevance today. Nuclear weapons have diminished the value of outright great-power war or even accepting the significant risks of war. Instead, nations today seek tactical relationships for achieving marginal bargaining advantages. Perhaps of greater importance, global interdependence is based on a system of complex forms of economic exchange, embedded norms and rules, and powerful international organisations and global firms. This creates powerful incentives for nations to avoid global confrontations and conflict. Both China and Russia need continued access to the global system more than they need each other. 
Russia and China cannot be seeking, nor are they likely to achieve, an alliance directed at the US or the Western-based global system. Rather, both China and Russia may hope they can act together to deter the West from imposing penalties should they seek to act outside the western-defined 'rules' of global relations. Should this succeed, they will be able to keep the gains from interdependence even as they avoid the consequences of 'bad' behaviour. And they can hope to reduce the effects of the structural power of the US, such as the power of the dollar as the world's key currency.

How effective a partner can Russia be for China? It has serious economic weaknesses, is based on a narrow and potentially unstable state, and is prone to reckless efforts at revanchism. How can Russia provide help to China in its ongoing conflicts with its neighbours? Even if China launches an equally misguided strategy of territorial expansion in Asia, Russia can offer little more than verbal support. The cost would come at exposing China to a conflict between Russia and the West.

It seems the combination of differentiated interests, the legacy of past conflicts, and global interdependence will condition and temper the scope and strength of the Sino-Russian relationship. For China and Russia, having any powerful allies is a worthwhile objective. But neither will find major gains from each other sufficient to make for a binding and substantial alliance relationship. EAFQ

Tom Lairson is the Gelbman Professor of International Business at Rollins College, Florida.

Ilan Alon is the Cornell Professor of International Business at Rollins College, Florida.

\section{Abe's quest for collective self-defence}

\section{BEN ASCIONE}

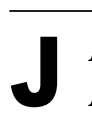

APANESE Prime Minister Shinzo

Abe and his Liberal Democratic Party (LDP) are currently negotiating with their coalition partner, Komeito, to introduce legislation recognising a limited exercise of collective selfdefence. There is rising anxiety about how this endeavour is perceived by Japan's neighbours and what affect this will have on regional stability, given the Abe cabinet's right-wing revisionist views of Japan's history.

At face value, the exercise of collective self-defence (that is, the use of force to come to the aid of an ally under attack) and historical revisionism may appear to be unrelated issues. But for Japan they are linked insofar as any Japanese government actions or statements that are perceived by its neighbours as whitewashing or denying the country's wartime transgressions cast doubt on the government's ultimate intentions about the character of Japan's defence policy. This is particularly so when those changes will expand the roles and functions of Japan's Self-Defense Forces (SDF). In this context, the historical revisionism of the Abe cabinet risks exacerbating the security dilemma in East Asia.

For countries such as the United States and Australia-which are eager to bolster their defence cooperation with Japan and encourage the SDF to move away from 'free-riding' by increasing its security burden-sharing roles - the situation raises a number of questions. How can the Abe cabinet be persuaded to dissociate itself from the historical revisionism that fuels regional distrust? And how can it be encouraged to engage in more active diplomacy to reassure China and South Korea that legitimate and limited upgrades of Japan's defence policy will not encroach upon their security? The answer to these questions is intimately linked to the historical trajectory that established Japan's postwar security policy status quo.

After Japan's defeat in World War II, the US-led Allied powers sought to demilitarise Japan. The new Japanese Constitution enacted in 1947 included the famous Article 9 'peace clause', which foreswears the use of force as a means of settling international disputes. The International Military Tribunal for the Far East (also known as the Tokyo Trials) was convened between 1946 and 1948 to try suspected Japanese war criminals.

The irony is that as the global security landscape shifted and the Cold War intensified, US concerns about a revival of Japanese militarism were outweighed by those about the Soviet Union. The US moved to reinvent Japan as an ally in the fight against communism and has urged its rearmament ever since. 


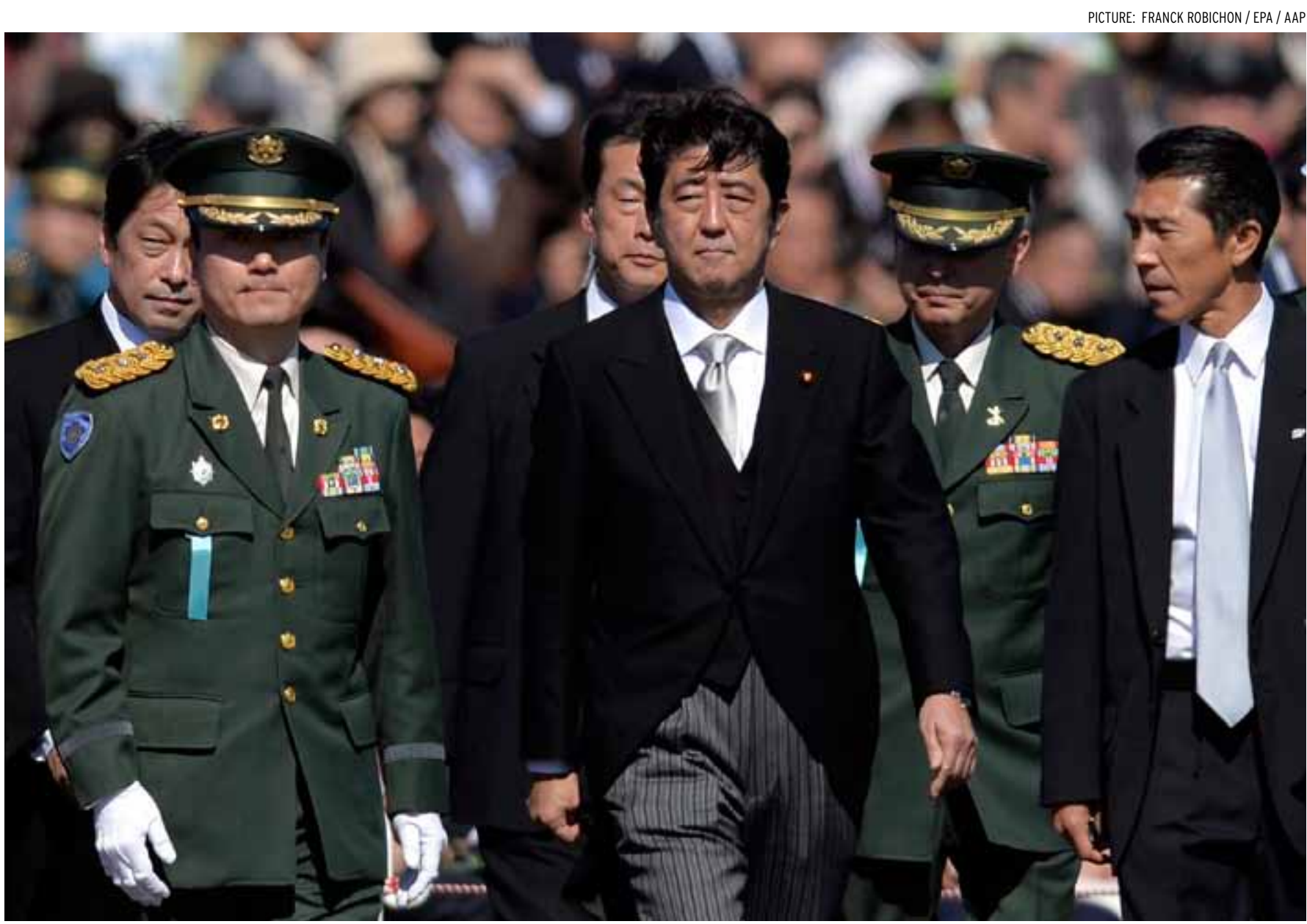

What role for Japan's Self-Defense Forces? Prime Minister Shinzo Abe with Ground SDF chiefs at the force's Asaka training ground in Tokyo.

Japan has made a number of incremental changes to its defence policy. A reinterpretation of Article 9 in 1954 allowed the SDF to be established. The SDF was permitted to use limited military capabilities for self-defence (jieiryoku) against a direct attack on Japan, so long as it did not possess 'war potential' (senryoku). Another reinterpretation gave birth to the concept of an exclusively defenceoriented security policy (senshu boei). This expanded the range of permitted military capabilities so long as they were confined to the 'minimum necessary level' to defend Japan and eschewed offensive power-projection capabilities.

After the end of the Cold War, with the direction of the US-Japan alliance under re-examination, new legislation allowed the SDF to provide rear-area support to the US military so long as it did not form an integral part in the use of force. The SDF is also permitted to be dispatched overseas in limited roles such as UN peacekeeping missions and humanitarian operations. But, despite US exhortations, Japan has maintained the senshu boei framework and its constitutional prohibition on the use of force outside of individual self-defence.

The US has become increasingly enthusiastic about Japan taking on greater defence burden-sharing in recent years. US President Barack Obama has emphasised multilateral cooperation, moving away from the hub-and-spokes system that characterised US security engagement in Asia during the Cold War and toward a denser web where all nodes are increasingly connected. US defence spending has been under strain in the wake of the billions spent on the wars in Afghanistan and Iraq, the global financial crisis, and budget sequestration. And, with the reelection of Abe in December 2012, the US has found a Japanese counterpart willing to undertake serious defence reforms.

So by an accident of history, the two groups most invested in expanding the roles and functions of the SDFAmerica's foreign policy and defence establishment and the revisionist Abe cabinet-find themselves as awkward counterparts with incompatible views 
on the history that underpins their alliance.

Right-wing revisionists, including many in the Abe cabinet, contend that the Tokyo Trials were nothing more than victor's justice. They resent the outcome as besmirching the honour of Japan's wartime military and the emperor in whose name Japanese soldiers fought. And they link what they perceive to be the Allies' distorted narrative surrounding the trials to the loss of Japanese autonomy over defence policy that Article 9 and the US-Japan Security Treaty entails.

The basis for questioning the Tokyo Trials sits largely on the deliberations of Indian judge Radhabinod Pal. Pal was the lone dissenting judge who, in an opinion released separately from the court, recommended that none of the war crimes suspects should be found guilty.

Pal's reasoning for recommending this verdict was driven by procedural concerns and his belief that there was no international law that made waging an aggressive war illegal. The category of 'crimes against peace,' which was used to deem a defendant a Class-A war criminal, was something that was made illegal retroactively after the war.

Pal recognised that the evidence of atrocities committed by the Japanese, such as the Nanjing massacre, was overwhelming. But he questioned the moral authority of a court composed only of Allied jurists to judge Japanese when the United States' dropping atomic bombs on Hiroshima and Nagasaki, not to mention the firebombing of Tokyo, were not held to account. Japan's right-wing revisionists have twisted and exploited Pal's words to deny any number of atrocities.

There is even a plaque honouring Pal at the controversial Yasukuni Shrine where the souls of 14 Class-A war criminals are enshrined.
From these origins, a polarising seed was planted in the politics of Japan's defence policy. Domestic opinion on defence policy is divided between antimilitarists, who favour a strict interpretation of Article 9; 'normal' nationalists, who advocate amending Article 9 so Japan may reform its defence policy to counter contemporary external threats; and historical revisionists, who view Article 9 as an unjust imposition by the US and advocate abolishing it.

Mainstream public opinion recognises that Japan's wartime military did inflict grave wrongdoings and supports the apologies for wartime conduct. But, under the Abe government, right-wing revisionists continue to be significant because of the sympathy for their views among the cabinet.

Almost half of the current Abe cabinet are members of the Association of Diet Members for Worshipping at Yasukuni Shrine Together, while another three have made visits to Yasukuni during their time as ministers. Abe himself controversially visited Yasukuni on 26 December 2013. This provoked criticism not only from China and South Korea, but also from the US,

Behind the flowery

language, their view of

history contends that

Japanese war crimes

... were exaggerated or

fabricated which noted that it was 'disappointed' by the move which will 'exacerbate tensions' with Japan's neighbours.

Abe has also made numerous appearances at events organised by the right-wing group Gambare Nippon! led by Toshio Tamogami, the former Air SDF chief of staff who was forced to resign because of an essay he penned arguing that 'Japan was ensnared in a trap' that led to World War II by the US. Abe and four others in his cabinet were among the sponsors of a protest advertisement run in the New Jersey Star-Ledger on 4 November 2012 by the self-proclaimed Committee for Historical Facts. The ad claimed that it was a 'gross and deliberate distortion of reality' to say the wartime Japanese government coerced the so-called 'comfort women' into sexual slavery.

More than three quarters of Abe's cabinet are also members of Nippon Kaigi (Japan Conference). Established in 1997, Nippon Kaigi positions itself as a grassroots organisation aimed at restoring a 'beautiful Japan' with a new constitution for a new era. Behind the flowery language, their view of history contends that Japanese war crimes, such as the Nanjing massacre, were exaggerated or fabricated. It also argues that Japan was liberating East Asia from Western colonialism and denies that the Japanese wartime military forcibly recruited 'comfort women'. Their vision of a 'correct' Japan appears to see collective selfdefence as a stepping stone to a more offensive military posture with full-spectrum power-projection capabilities. Nippon Kaigi seems bent on abolishing Article 9, taking an active approach to defending the disputed Senkaku/Diaoyu Islands and positioning Japan as a military superpower.

The dominant revisionist views 
of the Abe cabinet have come to the fore recently with the kerfuffle surrounding Japanese demands to revise references to 'comfort women' in an American history textbook, and in Abe's comments that the Class-A war criminals are not criminals under Japanese law and that academics have yet to agree on the definition of 'aggression'.

The questions of Japan's right to exercise collective self-defence under international law, and the potential security benefits to Japan from passing legislation allowing collective selfdefence under Japanese law, are in principle separate issues.

Collective self-defence would increase the deterrence capabilities of the US-Japan alliance. Without the right to exercise collective self-defence, Japan is not, for instance, permitted to shoot down a North Korean missile heading for the US. A limited exercise of collective self-defence to deal with such scenarios will help Japan to meet the demands of the contemporary security environment.

In terms of international law, Japan is well within its rights to exercise collective self-defence. It is a right that is guaranteed to all sovereign states under the UN charter and is the basis of NATO security, which deems an attack against one member-state to be an attack against all.

But any increased deterrence power that comes from Japan recognising the right to collective self-defence is highly likely to be offset when implemented by a government that is also espousing revisionist views of history. Irrespective of Japan's democratic institutions and the brake applied on the LDP by its coalition partner, Komeito, and mainstream public opinion, any moves to reinterpret Article 9 by a government associated with historical revisionist views will

PICTURE: KATSUMI KASAHARA / AP PHOTO / AAP

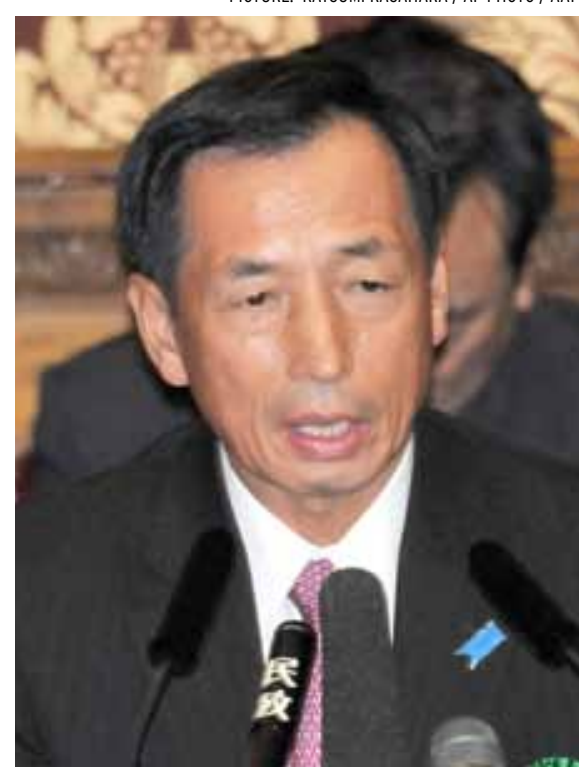

Former Air SDF Chief of Staff Toshio Tamogami, inaugural chairman of the Gambare Nippon!

fuel distrust of Japan. China and South Korea perceive this historical revisionism as evidence that Japan has neither faced up to nor regrets its wartime transgressions and that collective self-defence will be used as a stepping stone to further defence reforms that will negatively impinge on their own security.

Ultimately, therefore, this scenario risks undermining security in the region as China and South Korea may take countermeasures to bolster their security vis-a-vis Japan if they perceive Japan to be an increased threat. This, in turn, risks spiralling tensions and an arms race. Frictions over disputed territories could turn violent, tentative moves to repair Sino-Japanese relations could be undone, and hopes of promoting defence cooperation between Japan and South Korea as common US allies will be further complicated.

The US must be seen by all across Northeast Asia as seriously protesting against any revisionist views of history in the Abe cabinet. This is necessary to prevent Japanese politicians who advocate historical revisionism being further empowered, and to maintain America's strong cooperation with China and South Korea.

Abe faces two key tests in the coming months: a speech in May to the US Congress and a speech on 15 August to commemorate the 70th anniversary of the end of World War II. If in these speeches he unequivocally recognises the entire Murayama Statement-Japan's 1995 apology to its Asian neighbours for harm caused during the war-Abe can create a platform to begin to dissociate his cabinet from historical revisionism. This will help Abe to realise the exercise of collective self-defence in a manner consistent with his proclaimed desire for Japan to make active contributions to peace and regional stability.

At the same time, a gradual expansion of the SDF's roles and functions through collective selfdefence, focused on maximising Japan's security and bolstering the USJapan alliance's deterrence power, will serve to strengthen regional stability. But it will do so only if it is coupled with diplomacy to reassure Japan's neighbours and is purged of links to revisionism.

A legal basis for implementing collective self-defence should sensibly be built upon the foundation of the exclusively defence-oriented security policy framework that has served Japan so well in the 70 years since World War II and has been a force for peace in the region. EAFQ

\section{Ben Ascione is a PhD candidate at the Crawford School of Public Policy, The Australian National University. He is Japan and Korea editor at East Asia Forum and a research associate of the Japan Center for International Exchange in Tokyo.}




\section{Jokowi's turn to solve the Papua question}

\section{CILLIAN NOLAN AND SIDNEY JONES}

NDONESIA'S Papua, covering

its two easternmost provinces, simmers with the highest levels of deadly violence-inter-ethnic, electoral, land-related and domesticin the country. Home to a Melanesian and largely Christian indigenous population, it became part of Indonesia in 1969 after a highly contested referendum and has since been home to a low-level armed struggle for independence.

Papua's diverse population, with more than 200 distinct indigenous ethnic groups (and a large population of migrants from elsewhere in Indonesia), struggles with some of the lowest development indicators in the country. Successive Indonesian administrations have failed to solve these problems or reduce the grievances that fuel the independence movement. This is despite the gradual 'Papuanisation' of the local government bureaucracy since 1999 and the implementation of limited special autonomy since 2001. Will Indonesia's new President, Joko Widodo (Jokowi), who made the region a special focus of his 2014 election campaign, do any better?

The drivers of Papuan grievances include an influx of non-Papuan Indonesians, a failure to address isolation and poor social services in remote highland communities, and the need for more equitable sharing of Papua's vast natural resource wealth, including that derived from

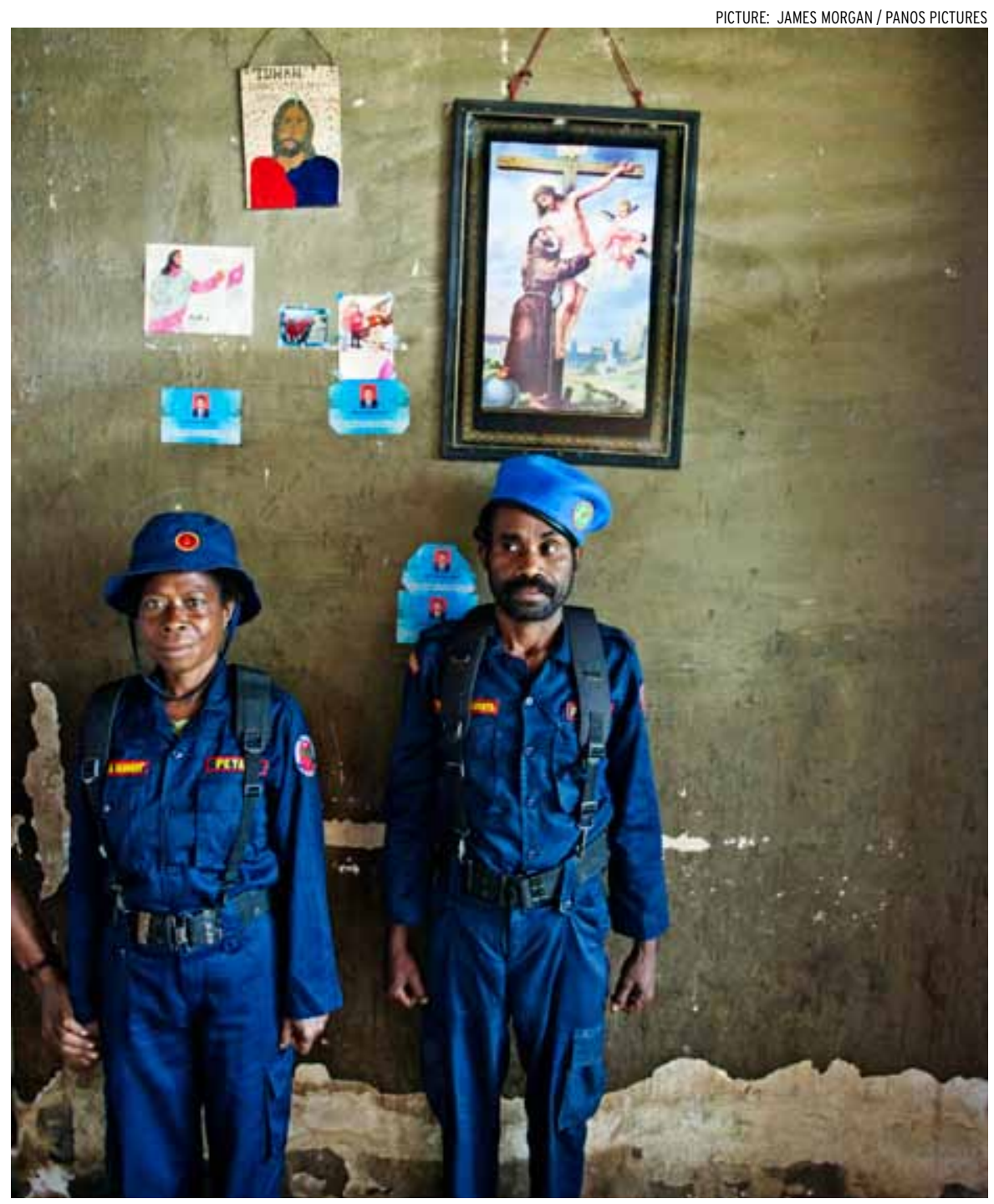

Two members of Balim Petapa, the community security guards unit formed by the Papuan Tribal Council. Gradual 'Papuanisation' has been under way during the past 15 years.

Freeport, the largest copper and gold mine in the world. There are also demands to acknowledge the violence and procedural shortcomings that accompanied the 1969 Act of Free Choice, to ensure more accountability for human rights violations, extortion and rent-seeking by security forces, and to improve governance without exacerbating inter-clan rivalries.

Successive governments have combined a 'security approach' and a 'prosperity approach' in different proportions. They have confronted the 
armed Free Papua Movement (OPM) with force and cracked down on non-violent pro-independence groups while simultaneously pouring in poorly targeted and supervised funds for 'development'.

Jakarta policy-makers and abusive security forces are not the only source of the problem. Local Papuan elites have not helped by competing with each other for spoils. Over the past five years civil society groups have demanded a 'dialogue' with Jakarta but lacked the focused agenda to drive one. And while willing to meet with these groups, senior Indonesian government officials have also been wary of anything that smacks of negotiation with a separate party. This is especially the case after Indonesia's experience with two other separatist areas: East Timor, which voted to break away in 1999, and Aceh, where a negotiated peace in 2005 led to the former guerrillas dominating local politics.

Jokowi's predecessor, Soesilo Bambang Yudhoyono, tried several initiatives that were well intentioned but ultimately failed. One was the creation of a government unit intended to coordinate programs across ministries in Papua with a focus on improving education and infrastructure. Hampered by resistance from the bureaucracy and poor leadership, it was disbanded not long after Jokowi's inauguration.

A second was a draft law on enhancing special autonomy, known as Otsus Plus, an effort to improve the 2001 law that after more than ten years had clearly failed to deliver benefits for Papuans. A draft law written by advisers to the two provincial governors focused too much on unrealistic increases in the value of central government transfers to Papua, but also included creative provisions on affirmative action for indigenous Papuans and protection for customary land and natural resource rights.

Proposals such as reserving smallholder plots in plantations, requiring resource investors to obtain the consent of indigenous communities and provide shares in compensation, and allowing communities to limit the in-migration of outsiders might all have restored a sense of meaningful local political autonomy absent from the 2001 law. But in the end, Otsus Plus also failed through a combination of disputes, delays and public anger over the lack of any consultation with civil society.

A third initiative in Yudhoyono's second term was a series of meetings with the main advocacy group seeking dialogue, the Papuan Peace Network (JDP). The meetings were exploratory rather than substantive, producing no policy changes before Yudhoyono left office. Their main success was to secure acknowledgement that dialogue-however it might be defined-was an important tool in conflict resolution.

It is now Jokowi's turn to look for solutions. But the situation on the ground is changing in a way that complicates matters for Indonesia's new president.

Expanding palm-oil plantations and mines, legal and illegal, have brought in more non-Papuan migrants

... the situation on the ground is changing in

a way that complicates matters for Indonesia's new president and increased Papuan migration across clan boundaries, sometimes bringing conflict in their wake. Local elections have pitted clans against one another, starting new feuds. The OPM has increased its attacks on soldiers and police, especially in the highland districts of Puncak Jaya and neighbouring Lanny Jaya. In response, the military and police increased their presence, adding a new police command in West Papua at the end of 2014. More and more new administrative districts have been carved out of existing ones in a way that threatens to further disperse the limited pool of capable civil servants.

Early proposals by Jokowi's cabinet ministers have done little to signal a new approach. They include suggestions to revive the old unpopular policies of transmigration and to increase administrative division. Vice President Jusuf Kalla, who helped broker the Aceh peace, has a long-standing interest in working toward a ceasefire with the OPM but earlier failed attempts have now given way to other priorities. Without a coherent policy that would address Papua in all its complexity, many are concerned that the new president will be pressured by conservative advisers who stress the 'security approach' to Papua.

If the new administration wants concrete ideas, it could do worse than to look back at Otsus Plus and start a new conversation on how to ensure that future large-scale development of Papua's vast natural resources does not crowd out Papuans themselves. In the meantime, the problems continue to fester. EAFO

Cillian Nolan and Sidney Jones are the Deputy Director and Director of the Institute for Policy Analysis of Conflict (IPAC), Jakarta. 


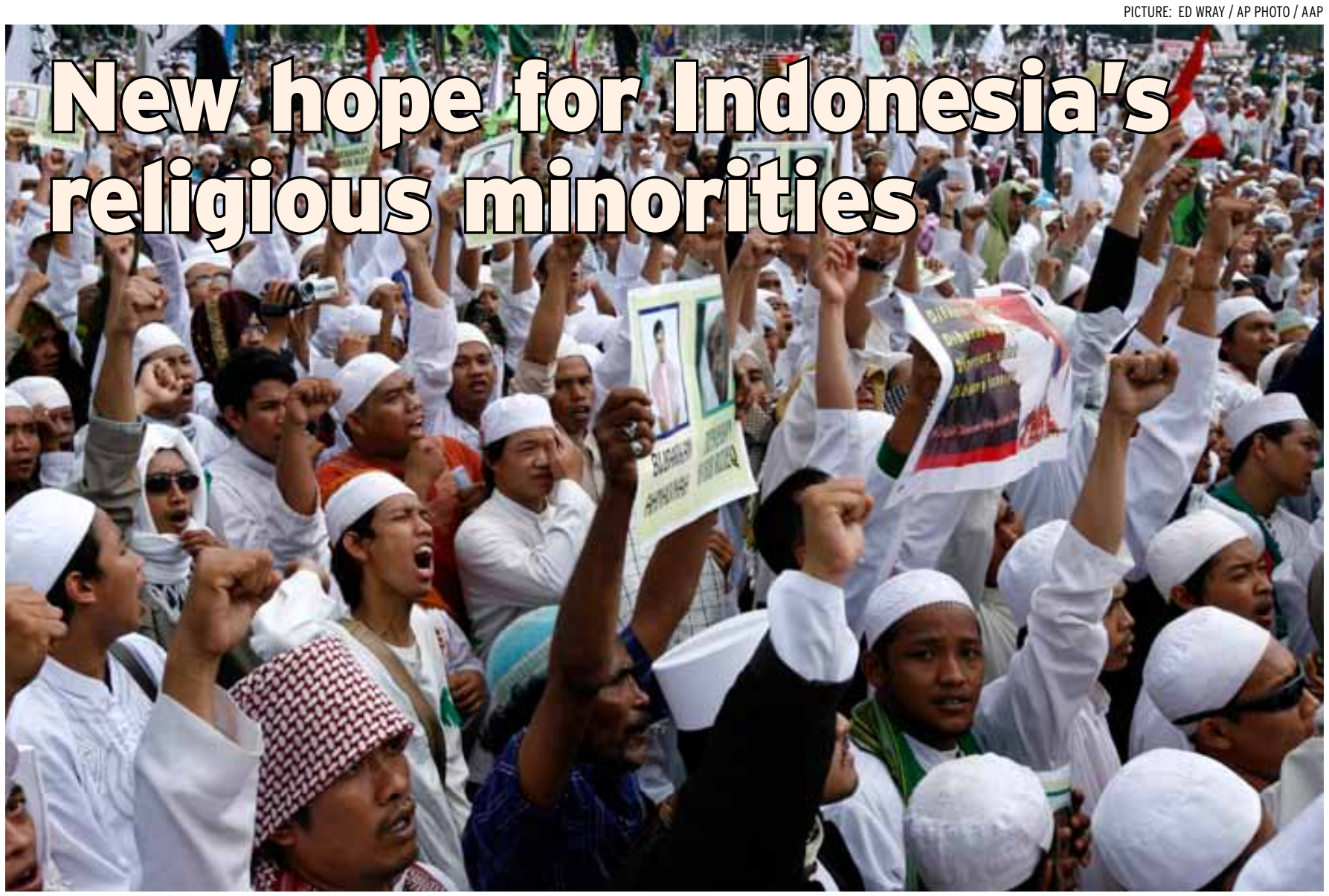

IHSAN ALI-FAUZI AND BEN HILLMAN

D URING the past decade attacks on religious minorities have cast a shadow over Indonesia's reputation as a tolerant and moderate Muslim-majority nation. Across the archipelago Christian, Buddhist, Ahmadi and Shi'ite communities have been exposed to increasing levels of discrimination, harassment, intimidation and violence, largely at the hands of Sunni hardliners.

On 29 May 2014, seven people were injured during attacks on a Catholic prayer service in Sleman, Yogyakarta. In June 2014, stone-throwing Sunni hardliners attacked a nearby church claiming it did not have a building permit. On 4 August 2013, a bomb exploded in a Buddhist temple in Jakarta, injuring three people. The

Demonstrators at this rally outside the presidential palace in Jakarta in 2008 called for Ahmadiyah to be disbanded. A range of subsidiary laws undercut constitutional guarantees of religious freedom.

following day Molotov cocktails were thrown into the yard of a Catholic high school in Jakarta.

Some of the most ferocious attacks have been directed at Indonesia's Ahmadi and Shi'ite communities. On 6 February 2011, an angry crowd in Cikeusik, Banten, murdered three Ahmadi men while a local policeman looked on. On 29 August 2012, more than 1000 Sunni villagers attacked a Shi'ite community on Madura Island, off the northeast coast of Java, burning homes and killing two people. The villagers were forced to seek refuge in a local stadium where they remained in temporary shelters for 10 months. On 20 June 2013, Sunni groups and religious leaders staged a mass protest to rid the stadium of the 'blasphemers', forcing the desperate leader of the Shi'ite community to agree to relocate the community to a town two hours away on the island of Java.

Rising intolerance toward religious minorities in Indonesia is a product of the spread of Sunni takfiri (extremist) ideologies, as well as the increasing activism of Sunni hardliners in Indonesia's democratic politics. State laws and regulations also facilitate intolerance and religiously motivated violence.

Indonesia's constitution guarantees freedom of religion but a range of national and local laws undercut the constitutional safeguard and provide a cover for religious bullies. The primary 
legal enabler of abuse against religious minorities is the 1965 Presidential Decree on the Prevention of Religious Abuse and/or Defamation (Blasphemy Law) which defines and criminalises 'deviant' religious practices. The Blasphemy Law remains in place despite the fact that Indonesia ratified the International Covenant on Civil and Political Rights in 2005.

Indonesia's highest Muslim clerical body, the Ulama Council, has also become increasingly active in identifying 'deviant' behaviour and issuing fatwas. On 21 January 2012 the Ulama Council of East Java declared that Shi'ism itself was blasphemous. This prompted a gubernatorial decree that imposed penalties on anyone who 'propagates blasphemous teaching.' The decree effectively legitimised violence against the Shi'ite community.

The preceding administration of Susilo Bambang Yudhoyono (SBY) was routinely criticised for its failure to protect the rights and welfare of Indonesia's religious minorities. At times the SBY government even appeared to encourage intolerant behaviour. In 2006 a Joint Ministerial Decree established the Inter-religious Harmony Forum, a council of religious leaders whose job was to facilitate the permit process for places of worship, but mounting evidence suggests that the Forum often hindered applications for Christian church permits.

More provocatively, in 2008 the government announced a Joint Ministerial Decree restricting Ahmadiyah activities outside of Ahmadi communities. SBY also appointed religious conservative ministers to parliament. They included Gamawan Fauzi, the minister for home affairs, who suggested relocating minorities rather than bringing their intimidators to justice, and Suryadharma Ali, the minister for
... Jokowi identified

\section{'intolerance and crisis in}

\section{the nation's character'}

\section{as one of the three}

main challenges facing

\section{Indonesia}

religious affairs, who publicly declared that Ahmadi and Shi'ites were heretics.

Hopes are now high among religious minorities that Indonesia's new President, Joko Widodo (Jokowi), will restore Indonesia's reputation as a tolerant and pluralistic Muslimmajority nation. Jokowi has a record of taking a pluralistic approach. As governor of Jakarta, he defended a Christian district head when radical Muslims attacked her credentials. He was also known for his close working relationship with his deputy governor, Basuki Tjahaja Purnama, who is Christian and of Chinese descent. Significantly, in his 2014 presidential campaign Jokowi identified 'intolerance and crisis in the nation's character' as one of the three main challenges facing Indonesia.

Jokowi's pluralism and religious tolerance are demonstrated through

\section{EASTASIAFORUM}

IN OUR NEXT ISSUE ...

\section{Leadership in the region}

his political support base. He is backed by secular pluralist parties, such as the Indonesian Democratic Party of Struggle and the National Democratic Party, and pluralistic Islamic scholars. He is also backed by the National Awakening Party, which is closely affiliated with the largest moderate Islamic organisation in IndonesiaNahdlatul Ulama.

Although Jokowi has yet to make any public statements on the question of religious minority rights, at the end of 2014 his newly appointed Minister for Religious Affairs, Lukman Hakim Saifuddin, announced plans for new laws to protect religious communities. This is a promising step but, unless the 1965 Blasphemy Law is rescinded, it is unclear how much impact the new law will have.

It also remains to be seen whether Jokowi will be able to shepherd such a law through Indonesia's rambunctious parliament. With only 37 per cent support in the parliament, passing any legislation will be difficult for Jokowi. And there is no sign that the protection of religious minorities will be a legislative priority. The minister's bill could languish for years. It will be even more difficult for the Jokowi administration to deal with the often discriminatory Sharia-based by-laws passed by regional governments.

If Jokowi believes that 'intolerance and crisis in the nation's character' is one of the biggest problems the country is facing, it is not yet clear how he plans to solve it. EAFO

Ihsan Ali-Fauzi is the Director of the Centre for the Study of Religion and Democracy at Paramadina University, Jakarta.

Ben Hillman is a Senior Lecturer at the Crawford School of Public Policy at The Australian National University. 


\section{Missing the peace in Muslim Mindanao}

\section{PATRICIO N. ABINALES}

5

HERE is still no peace in Muslim Mindanao. A recent agreement to grant the region autonomy had support but is now in limbo after 44 policemen were killed in the region on 25 January 2015. So why has peace eluded Mindanao for so long? And how much longer will Mindanao have to wait for the missing peace?

A major reason behind the historical inability to come up with a cohesive and lasting peace plan for Mindanao has to do with an orthodox explanation. An explanation that is shared by the most disparate of social and political forces-government officials, Muslim separatists, communists, public intellectuals, the media and even all-knowing development experts. It is an orthodoxy that has consistently promoted a narrative that assumes a history of unceasing conflict on the country's second biggest island. It puts a high premium on minority-majority tensions, religion as an inspirational force for armed change and the omnipresence of a capable state and its coercive apparatuses in the Philippine south.

On the contrary, Muslim Mindanao has a far more complex history, and this is what the orthodoxy has papered over. Conflict, in particular, has been the exception rather than the rule, and where it did happen this was mostly caused by factors other than religion. The orthodoxy has not only widely exaggerated the omnipresence and capacity of the Philippine state but also

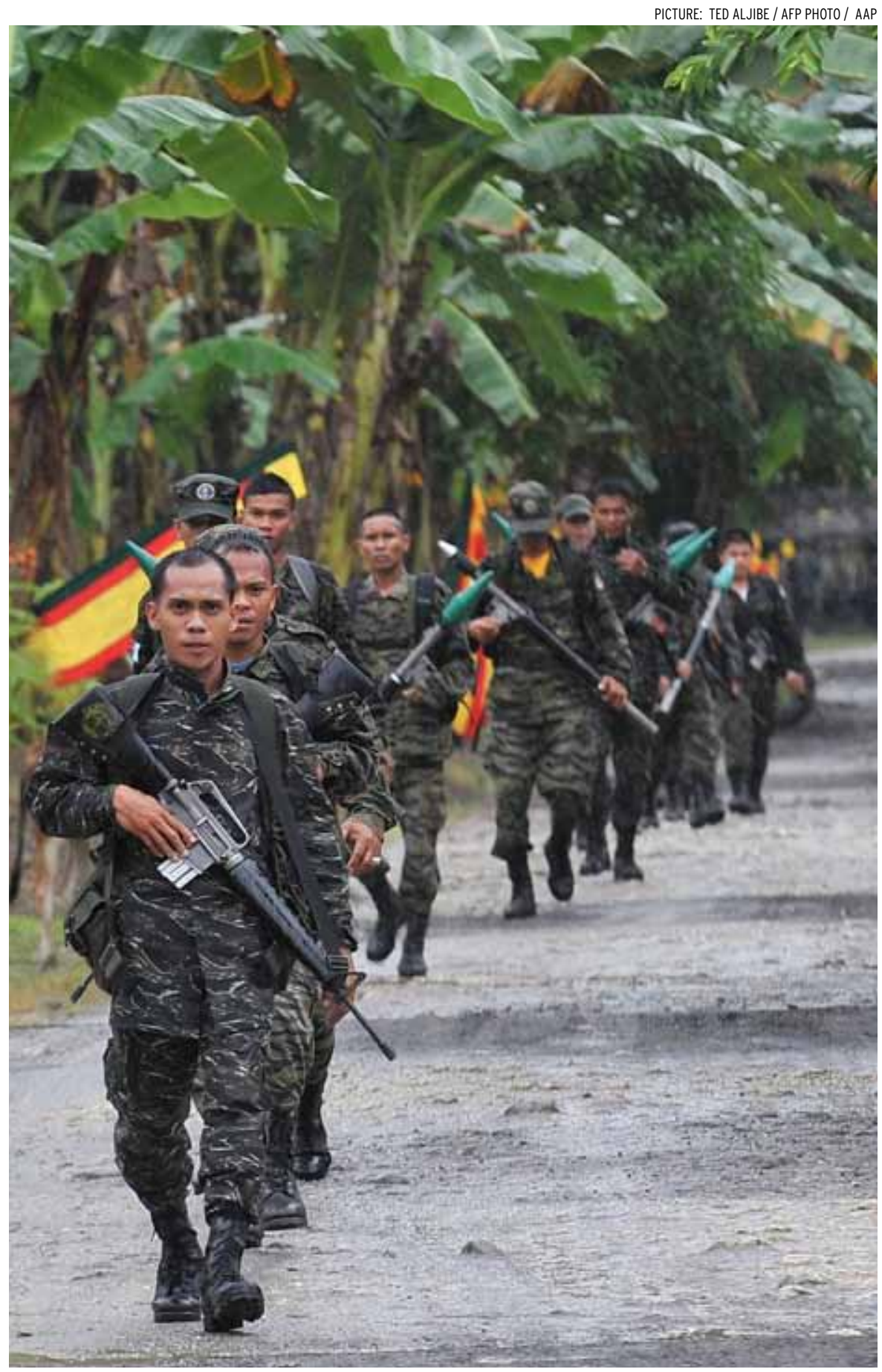

A Moro Islamic Liberation Front patrol in Mindanao. Though a formidable military opponent, the group was not able to expand the amount of territory under its control. 
understated the power of local Muslim elites-and, as such, underestimated their role in both the war and the quest for peace in the umma (nation).

Conflict with the state has been intermittent. During the colonial period revolts were few, and when they did occur they were motivated less by grand visions than by localised exigent demands, including taxation, abuses by colonial officials, the end of the slave trade, and intra-elite conflict. These multifaceted and localised forms of militant engagement with outside powers continued to be the norm even in the era of the separatist rebellions

Resistance was also paralleled by a prolonged period of Muslim collaboration with their supposed enemies. Muslim elites did not hesitate to work with national partners to keep their authority over their local constituents. This is the singular advantage that these 'traditional' leaders armed with modern political designations (senator, congressman) have over their rebel rivals. With their longer history, social embeddedness, and ability to make political adjustments, Muslim elites have come to outwit the state and outlast the separatists. Manila's authority in the Muslim zones was and continues to be mediated through local power.

The orthodox narrative also highlights the various government colonisation schemes as a cause of the conflict. What it does not tell us is that these programs failed. They fell victim to limited budgets, corruption and inefficiency in Manila as well as in the field sites. A Land Settlement Development Corporation became 'an agency of incompetent political appointees and corrupters' that made, as US agriculture expert Merrill Abbey points out, the 'fast clearance of land titles next to impossible to accomplish'. The Bureau of Lands, which was

\section{Many MNLF leaders}

\section{established themselves}

\section{as new players in their}

localities ...

supposed to oversee the organised distribution of homestead settlements, was, as economist Peter Krinks contended, "hampered by the wartime destruction of records, the lack of funds and by the illicit intervention of politicians. The consequences of this inefficient state delivery system were dramatic. Hunger and famine stalked many communities.

But the clashes only started with the filling up of the frontier and the determination of President Ferdinand Marcos to assert central state authority. By the 1960s spontaneous migration filled up the frontier as 1.2 million people settled in the region. But this alone did not immediately lead to clashes with Muslims. Settlers and Muslims coexisted peacefully, trading in marketplaces where goods and harvests were sold. Peace was ensured by the Muslim elites who saw the settlers as new electoral constituents. But then President Ferdinand Marcos asserted central state authority.

In his first three years in power, Marcos vowed to pursue an economic program that would integrate Mindanao into the national development plan. He reconfigured local politics by promoting new strongmen and expanded the national army's presence all to challenge the old Muslim elites. All these became the catalysts for the first separatist war led by the Moro National Liberation Front (MNLF) - the Philippines' only conventional war after World War II.

But after more than a year, battlefield losses forced the MNLF to revert to guerrilla warfare. The organisation also split with the largest breakaway group forming the rival Moro Islamic Liberation Front (MILF). Marcos fell in 1986 and his successor, Corazon Aquino, restored constitutional politics.

The MNLF splintered further after 1986 and an ageing and tired leadership finally signed a peace agreement with the government 10 years later. Many MNLF leaders established themselves as new players in their localities, becoming legislators, provincial governors and city and town mayors.

The MILF filled the void left by the MNLF, flexing its muscle in a series of brutal confrontations with the army in the late 1990s and early 2000s. But its war was largely defensive, and it was never able to expand the area under its control. After a series of failed negotiations, the MILF finally signed an agreement with the government on 24 January 2014. MILF agreed to the creation of a new autonomous region with the power to raise its own revenues and have its own regional army. A bill was then introduced for the Philippine legislature to pass.

But on 25 January 2015, a secret police operation to capture two terrorists hiding in MILF territory turned awry and 44 policemen were killed. An angry public forced supporters to postpone legislative hearing on the bill. There was unanimity that the MILF was at fault and must account for the massacre.

And now there is still no peace in Muslim Mindanao. EAFO

Patricio N. Abinales is a professor at the Asian Studies Program, University of Hawaii, Manoa. 


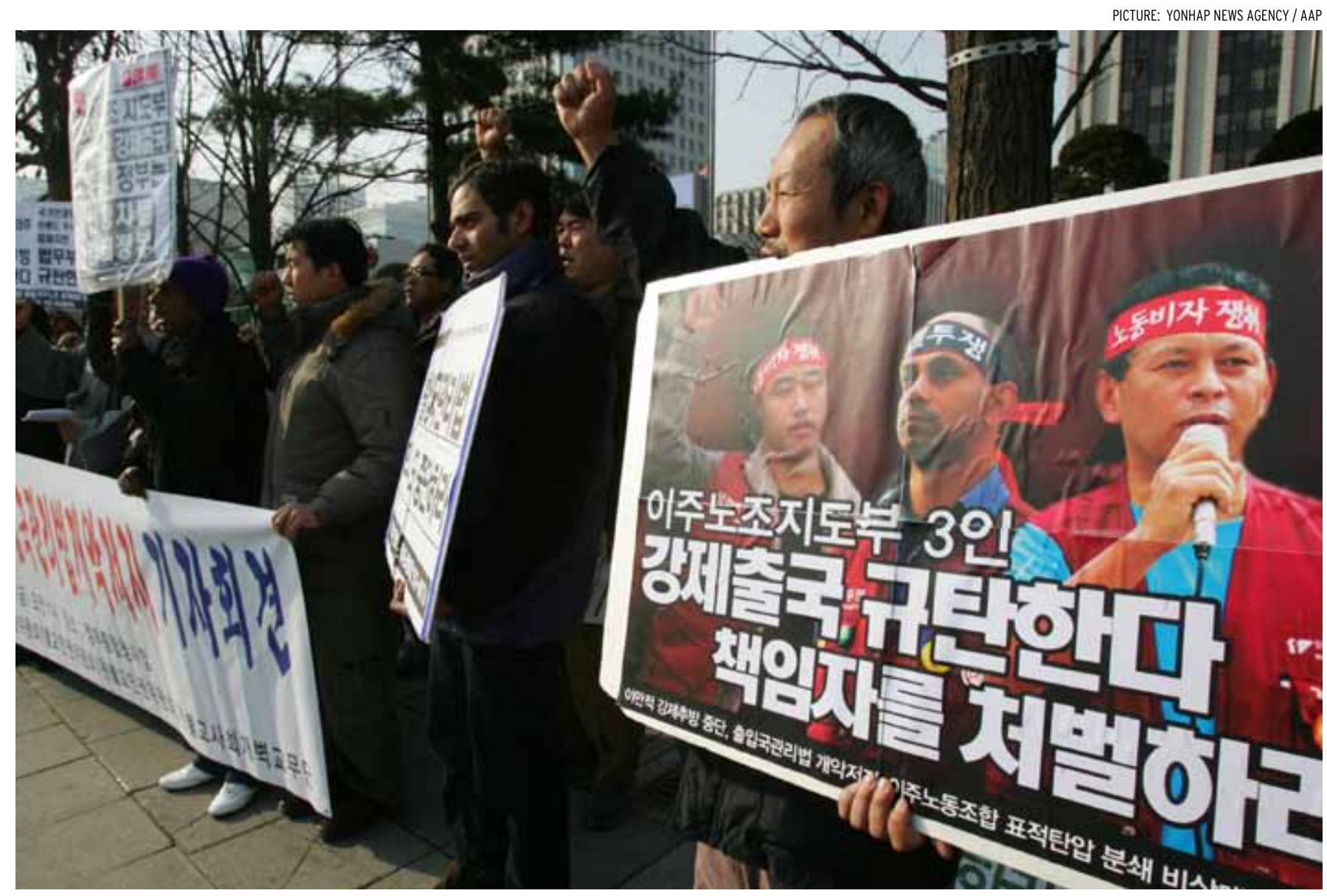

Activists in Seoul protest against the forced deportation of illegal migrant workers. Foreign workers 'continue to experience abuse and exploitation'.

\section{How ethnic nationalism undercuts multiculturalism}

\section{EUN JEONG SOH}

N

ORTH and South Korea are widely regarded to be ethnically homogenous societies. But with minority populations having grown in numbers and importance in both Koreas, demographic homogeneity has become a myth.

Yet the importance of ethnic nationalism as an underlying identity of the two states prevents a genuine transition to a multicultural society in both cases. In both Koreas, policies that disproportionately focus on reaping benefits from minorities, and a lack of public consensus on what constitutes multiculturalism, have led to human rights violations and social conflict.

The ideal of creating a modern nation-state for the Korean people underpinned the founding of both North and South Korea. But the nation-building process also produced minorities. In South Korea, discrimination on the basis of regional origin increased under the authoritarian regimes led by Park Chung Hee and Chun Doo Hwan and continues in public discussions today. In North Korea, the social stratification (songbun) system divides the population into three major categories, and 51 subcategories, on the basis of how one's grandparents participated in the emerging state's anti-colonial communist revolution.

The most important minority group in South Korea today is ethnic Korean Chinese. Increasing numbers of ethnic Korean Chinese have migrated 
to South Korea under the diaspora (dongpo) policy, which loosened entry and residency regulations. Today, the ethnic Korean Chinese population in South Korea reaches 500,000-39 per cent of the total foreign nationality population. Despite sharing the same language and working in sectors where there is the most need, ethnic Korean Chinese continue to face prejudice and discrimination from broader South Korean society.

South Korea's migration policy is designed to satisfy small- and medium-size businesses' demand for cheap labour. This policy focus means the rights of migrant workers have not been protected effectively. Under the Employment Permit System, adopted in 2004, migrant workers continue to experience abuse and exploitation. They face restrictions when changing workplace and are prohibited from forming or joining labour unions. A 2014 Amnesty International report detailed abuses of migrant workers in the farm and fishery sectors and recommended that the government allow workers greater freedom to change workplace and enforce work condition standards across all sectors.

Marriage migrants also face problems. In rural areas, the majority of marriages-236,000 in total-are between a Korean man and a foreign bride. Cultural differences in this maledominated family setting can create major difficulties, and family discord and domestic violence are common. One counselling centre received 5000 requests for divorce counselling in 2014. In that same year, 69 per cent of immigrant wives suffered abuse. Seven of these women were murdered by their partners.

Civic, religious and feminist groups run shelters for immigrant women facing divorce proceedings, who risk having their residency revoked. There are 100 multicultural support centres nationwide that run incipient conflict resolution mechanisms and seek to represent the interests of immigrant wives. Jasmin Lee, a naturalised Filipino-Korean elected in 2012, is the first advocate for immigrant wives in the National Assembly. Lee faced racially-charged attacks, demonstrating a general insensitivity to multiculturalism in South Korea.

Another minority group in South Korea is made up of North Korean defectors, who number now only 27,500-a miniscule number compared to other minorities. Like other minorities, these defectors face prejudice and difficulties in adjusting to their new home country. Conflicts involving North Korean defectors have been politically charged: either silencing their voice if it is inconvenient for the government's unification policy or mobilising it to strengthen an anti-North Korean stance.

Defectors are subject to another danger: accusations that they are spies. This danger was recently

Marriage migrants

also face problems ...

Cultural differences in this male-dominated family setting can create major difficulties, and family discord and domestic violence are common highlighted in the case of Yoo Woosung, a defector and former employee of the mayor of Seoul's office. Yoo was acquitted for espionage after the National Intelligence Service was found to have forged evidence.

In North Korea, Korean expatriates returning from Japan and China have a distinctive place in society. Repatriates from Japan and China offered technical expertise and skilled labour during the post-war reconstruction period. The North Korean government benefited from the currency transactions and in return permitted them a greater level of economic freedom. But, at the same time, repatriates and their children have also faced systematic discrimination in pursuing political careers as party cadres and security officials. Since the 1990s, repatriates who have relatives outside North Korea have had a greater advantage in conducting trade and in even attempting defection.

Policies for handling minorities in the two Koreas demonstrate an absence of a clear long-term vision. There is no public consensus on how, and even if, either Korea should transform from an ethnic nation to a multicultural one. Despite the prevalent use of the term multiculturalism in South Korea, there is little public discussion or shared understanding as to what it is. Incoherent policies designed to yield benefits from minority groups and assimilate them into broader society continue to produce human rights violations and social conflicts. Unless a coherent approach to multiculturalism is developed, similar outcomes may well be reproduced in a possible future reunification process. EAFQ

Eun Jeong Soh is a post-doctoral fellow at The Australia National University. 


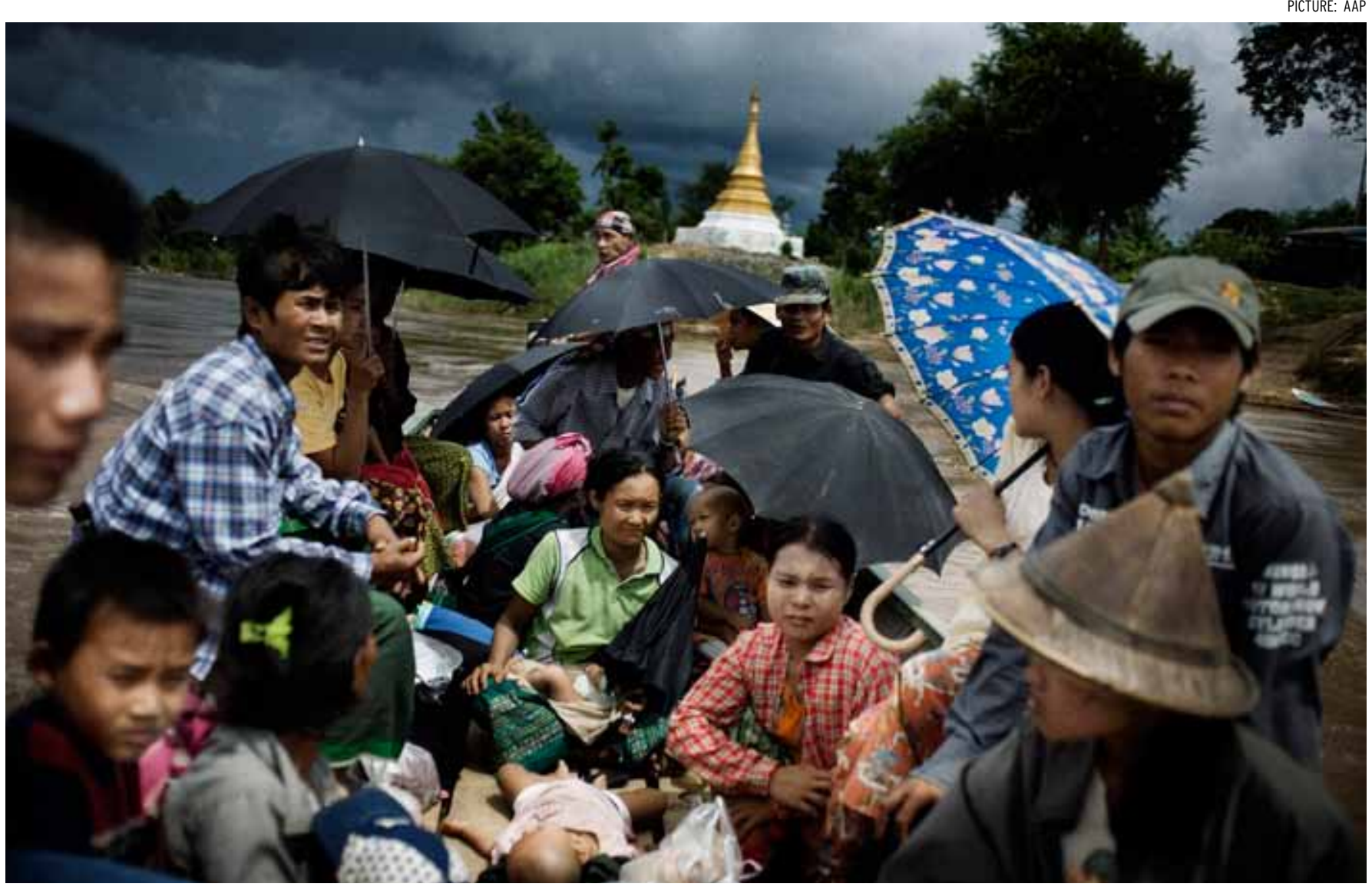

Karen people crossing from Myanmar to a clinic in Thailand. There are still no peace agreements in place between major ethnic groups and the government.

\section{Compromise essential to resolve a conundrum}

\section{NICHOLAS FARRELLY}

- OR decades civil wars have raged along Myanmar's ethnic fault lines.

In the official count the country tallies up 135 different 'national races'. The majority Bamar people, who drive national expectations of language, culture and politics, make up around 60 per cent of the population. The minority groups, most with their own distinct tongues, customs and clothes, make up the rest.
This ethnic diversity ranges the length and breadth of the country but is concentrated in the highlands. It is from these remote regions, nestled against the borders with Bangladesh, India, China, Laos and Thailand, that other influences are drawn into the Myanmar fray. Every central government has struggled with this intermingling of diversity, and the power of cross-border connections.

In response, government policy has sought to enforce a single centralised union, where minority claims to self- determination and autonomy have been vigorously stamped out.

That the best organised of the ethnic groups have resisted these efforts has led to rolling civil war, going right back to the 1940s. The major ethnic armed groups-such as the United Wa State Army, Kachin Independence Army and Karen National Liberation Army-are the product of these decades of antigovernment insurrection.

For the past quarter century the government has sought to arrange 
ceasefires with its armed opponents. These have proved only moderately successful.

Indeed there are still no final peace agreements and the precarious status of the ceasefire deals ensures they are subject to regular renegotiation. In 2014 the government made an extra push to finalise a nation-wide peace agreement in the lead-up to the 2015 general election. It is unclear when the final deal will be done.

For now, this leaves the government with an array of unwieldy issues to manage. There is the need, from the official perspective, to ensure that national unity is maintained. In the context of Myanmar's guiding narrative of harmony and inclusion the rumblings of ethnic armies and their secessionist struggles have been inconvenient. Understanding the aspirations of ethnic peoples has required patience and savvy.

Offering economic incentives and concessions has proved one effective strategy. Ceasefires in Myanmar have tended to be accompanied by commercial tie-ups that have funnelled new wealth into the pockets of ethnic leaders. With abundant
Ceasefires ... have tended to be accompanied by

\section{commercial tie-ups that have funnelled new wealth}

\section{into the pockets of ethnic leaders}

mineral reserves, to say nothing of the money to be made from trade, logging and construction, there has been much wealth to go around.

A number of Myanmar's most successful companies, including the gigantic Asia World conglomerate and the politically potent Jadeland, have emerged directly from the ceasefires. Ethnic commercial leaders, their coffers bursting with loot, have often worked with the government to weld peaceful interactions together.

Such arrangements have been subject to turbulence, with some of the key ceasefires breaking down in recent years. In 2011, for example, the Kachin Independence Army went back to war with the central government after a 17-year truce. The new war was bloody, with reports of thousands of casualties in the two years of heavy fighting. More than 100,000 people were displaced from their homes. Even though most of the fighting is over, many are still languishing in hastily constructed camps in Kachin State and northern Shan State. Some of these refugees were forced to huddle together along the border with China as the war raged around them.

This pitiable situation has been the experience for generations of people from minority backgrounds, with millions forced to find sanctuary in Thailand, Bangladesh, Malaysia and further afield. Myanmar government counter-insurgency campaigns have often worked to eliminate the support that villagers and townsfolk offer ethnic rebellions. The results are found in long lists of egregious human rights violations. The trauma of these wars is no small thing.

With this history, precisely how the Myanmar government should

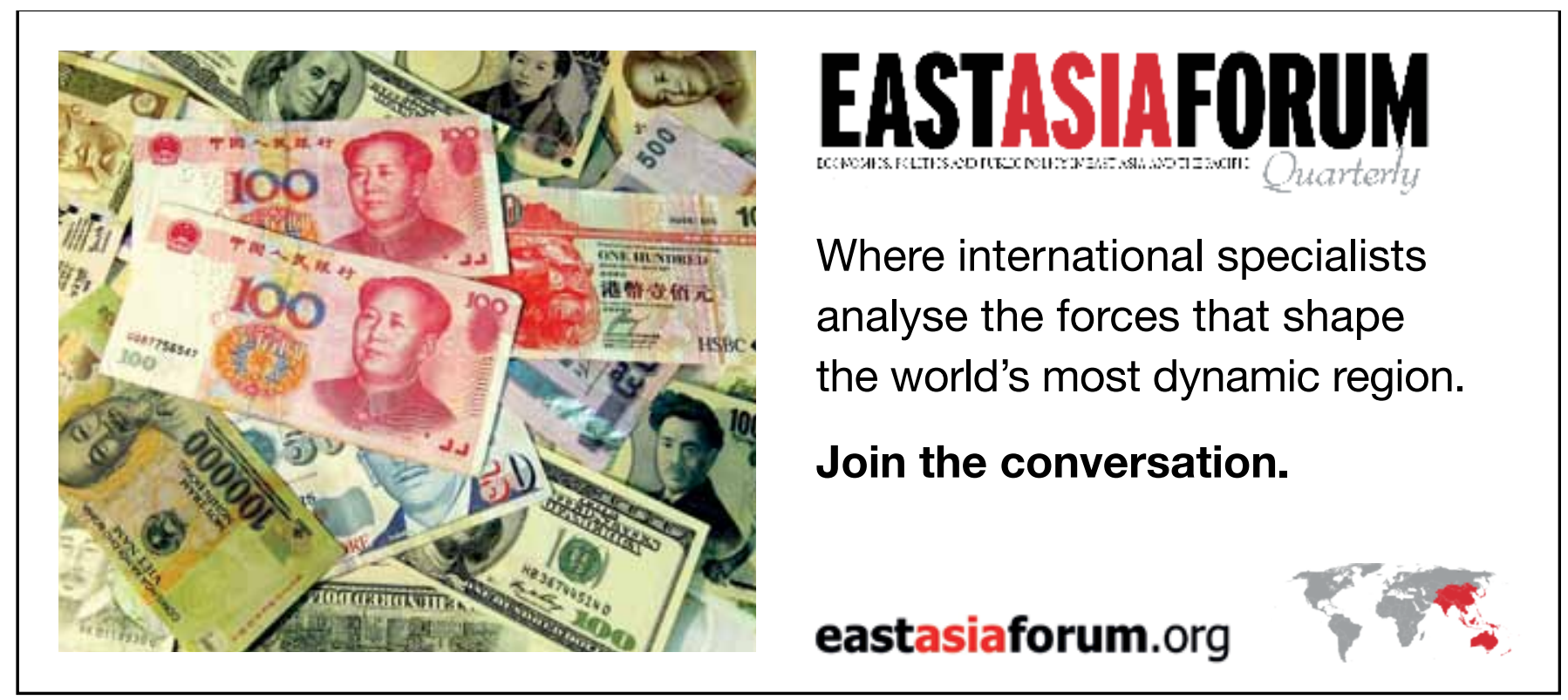




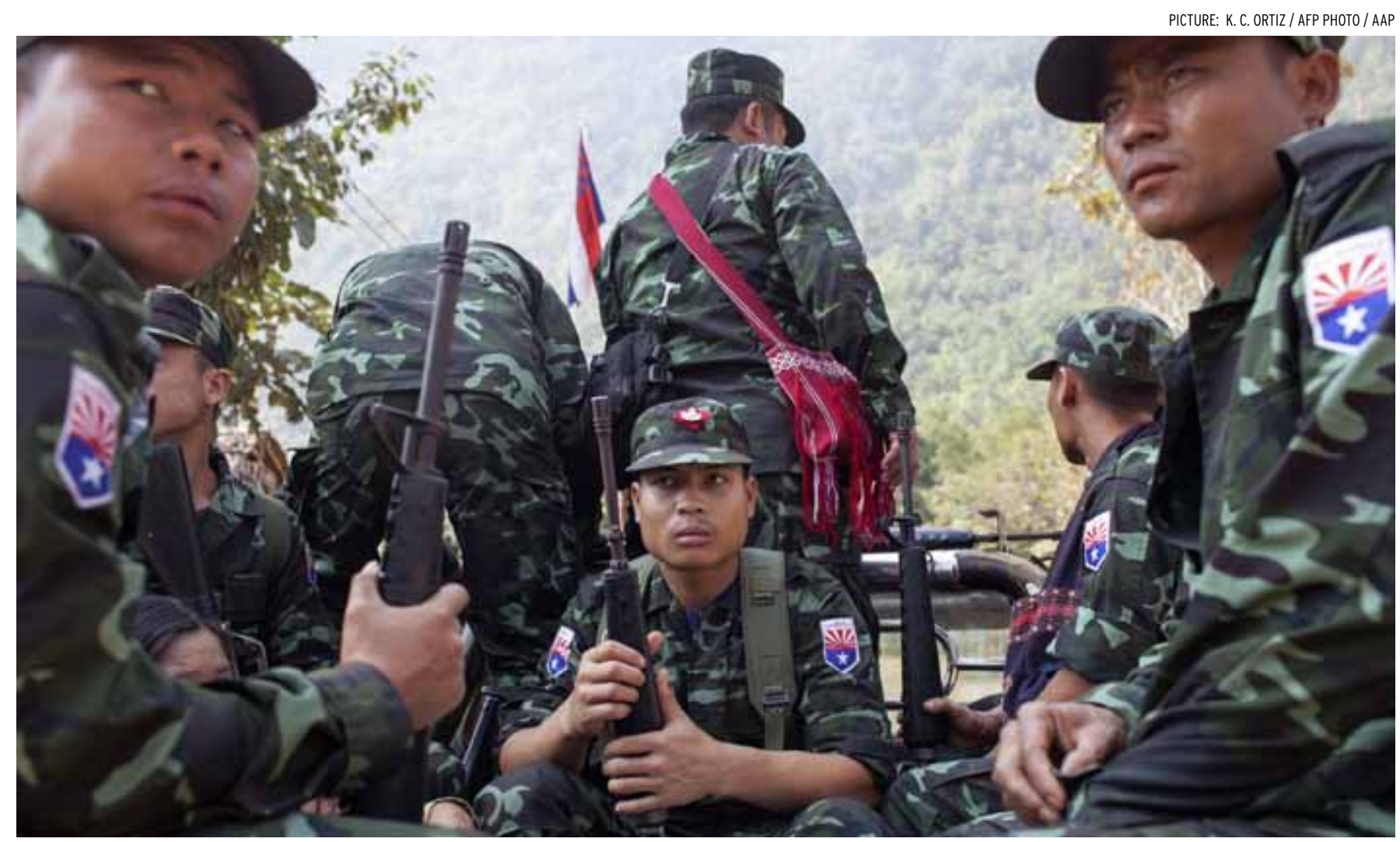

Karen National Liberation Army troops returning to active duty in January 2015. Sporadic fighting continues, despite hopes for a nation-wide peace.

best include minorities in the ongoing national reform process is the subject of much debate. It all hinges on the result of the next election, scheduled for later in 2015.

Looking at the electoral maths, minority voters are likely to disperse their affections across dozens of parties. The election result, and the shape of the next government, will thus be determined by the performance of the opposition National League for Democracy and the incumbent Union Solidarity and Development Party.

Both of these major parties also draw support from ethnic voters and will offer candidates from ethnic minority backgrounds in 2015. In many areas they will go toe-totoe with popular alternatives from different ethnic minority political parties. Powerful Mon, Karen, Shan, Chin, Kachin and Rakhine parties are expected to do well in their areas of the country. Most analysts expect the ethnic vote will fracture wildly, meaning that some unexpected victories will occur in a first-past-thepost system where second preferences count for nought.

While it doesn't get the attention it deserves, it is this emerging pattern of complex ethnic politics, partly driven by the government's co-optation of ethnic leaders, that will likely determine just how successful the overall reform process becomes.

The bottom line is that if Myanmar's minorities can't find sufficient space for their cultural, political and economic interests then the alternative, history suggests, is further war.

To avoid that prospect Myanmar's majority Bamar population will need to more fully accommodate the aspirations of those minorities who find the union an uncomfortable place to be. Rhetoric of national belonging and inclusion rings hollow after so many decades of torrid conflict. The goal for the Myanmar government must be to find a sustainable approach to managing these problems.

That means sharing much more power and listening much more carefully. For long-term happiness, Myanmar's minorities will be seeking greater autonomy and the chance to defend their cultural heritage. Even if all goes well, balancing their interests against those of the majority will be a permanent conundrum. EAlPQ

\section{Dr Nicholas Farrelly holds an} Australian Research Council fellowship for a study of Myanmar's political cultures 'in transition.' He is also the co-founder of New Mandala and the Director of the ANU-IU Pan Asia Institute. 

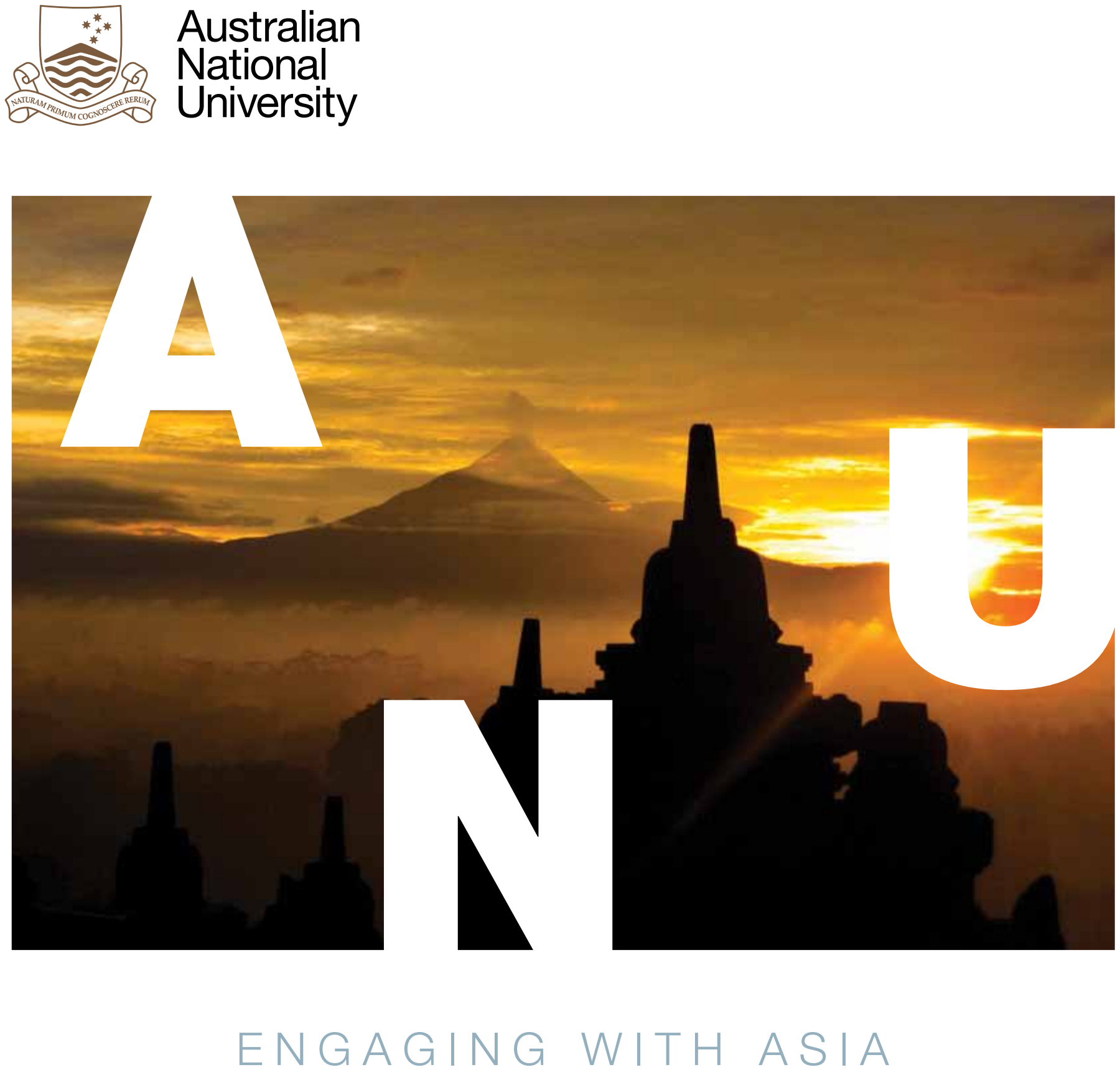

Crawford School is The Australian National University's public policy school, leading and shaping public policy debate in Australia, Asia and the Pacific, through research, professional education and policy engagement. Staff and visitors are active on government committees and play advisory roles across government, business and civil society.

At Crawford School, you will be part of Australia's premier public policy community. Explore your graduate coursework, research and executive education study options in the following fields:
> Public Policy

> Public Administration

$>$ International and Development Economics

$>$ Environmental and Resource Economics

$>$ Environmental Management and Development

$>$ Climate Change

> Applied Anthropology and Participatory Development

Join Australia's leading public policy community today. 